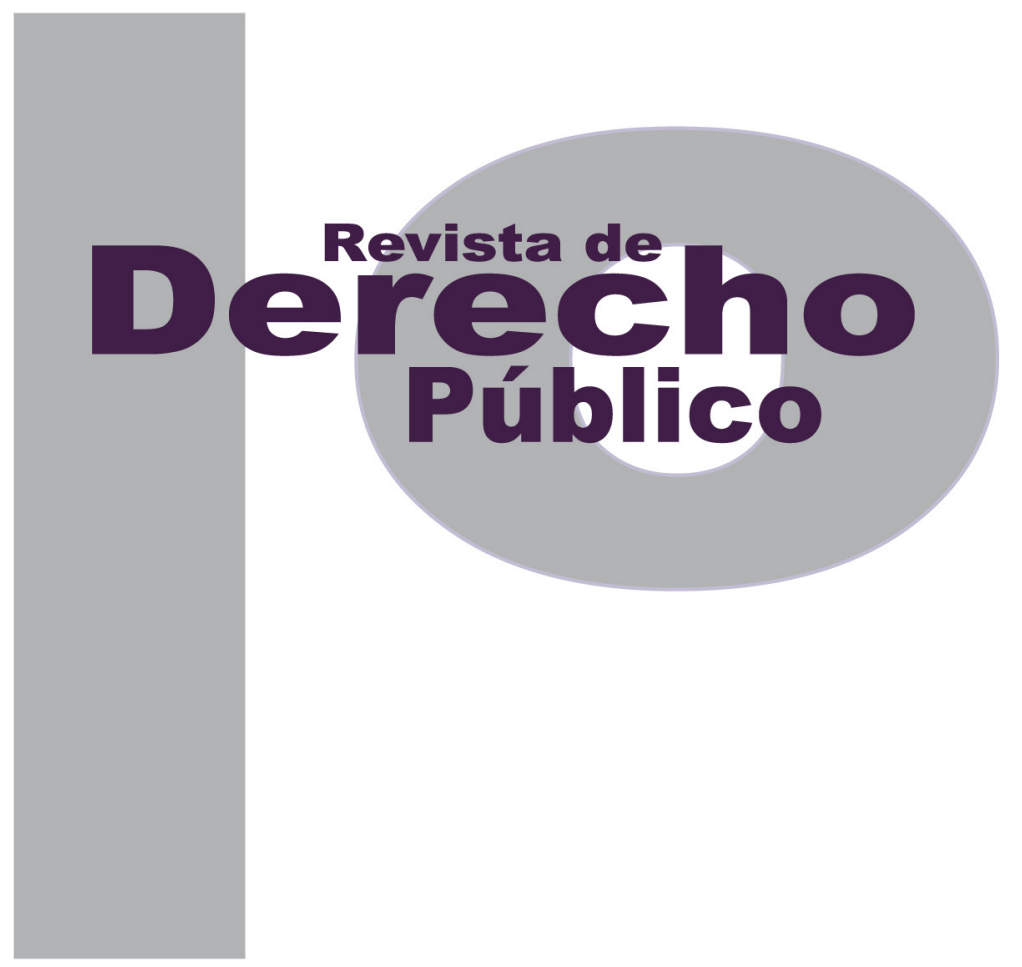

RESPONSABILIDAD 0 SOLIDARIDAD.

EL FUNDAMENTO DEL DEBER DE REPARAR EN EL ÁMBITO DE LA RESPONSABILIDAD EXTRACONTRACTUAL DEL ESTADO

JULIÁN ANDRÉS PIMIENTO E.

Artículo de reflexión

DOI: http://dx.doi.org/10.15425/redepub.36.2016.14

Universidad de los Andes

Facultad de Derecho

Rev. derecho publico No. 36

enero - junio de 2016. e-ISSN 1909-7778 


\section{Responsabilidad o solidaridad. \\ El fundamento del deber de reparar en el ámbito de la responsabilidad extracontractual del Estado}

\section{Resumen}

Desde la promulgación de la Constitución Política de 1991 en alguna parte de la doctrina y en buena parte de la jurisprudencia se ha intentado encontrar el fundamento del deber de reparar en el principio de solidaridad. Tal posición se considera equivocada y solo se explica por una deformación de la institución de la responsabilidad extracontractual del Estado derivada del conflicto armado que aqueja al país. No puede haber responsabilidad patrimonial del Estado sin que el daño cuya reparación se pretende le pueda ser imputado a una entidad pública. En este escrito se busca probar porqué el juicio de responsabilidad patrimonial del Estado y su escenario procesal, la acción de reparación directa, son inadecuados para desarrollar el mencionado principio de la solidaridad.

Palabras clave: principio de solidaridad, responsabilidad del Estado, Consejo de Estado, conflicto armado, acción de reparación directa, imputación, imputación objetiva, daño especial.

\section{Responsibility or solidarity? The foundation of public tort law}

\section{Abstract}

Since 1991, Colombia's Constitution, doctrine and judicial decisions alike have tried to find public tort law foundation in the principle of solidarity; in our view, such an approach is not adequate. For there can be no liability without a proper analysis of damage allocation to a public entity. This article seeks to demonstrate that public tort law and civil actions against State and local authorities are not a proper scenario for the principle of solidarity to be applied.

Key words: Principle of solidarity, public tort law, armed conflict, civil actions against state and local authorities, allocation of damages, objective imputation, special damage.

\section{Responsabilidade ou solidariedade. O fundamento do dever de reparar no âmbito da responsabilidade extracontratual do Estado}

\section{Resumo}

Desde a promulgação da Constituição Política de 1991 em alguma parte da doutrina e em boa parte da jurisprudência se tem tentado encontrar o fundamento do dever de reparar no princípio de solidariedade. Tal posição se considera equivocada e só se explica por uma deformação da instituição da responsabilidade extracontratual do Estado derivada do conflito armado que afeta o país. Não pode haver responsabilidade patrimonial do Estado sem que o dano cuja reparação se pretende lhe possa ser imputado a uma entidade pública. Neste escrito se pretende provar porque o juízo de responsabilidade patrimonial do Estado e seu cenário processual, a ação de reparação direta, são inadequados para desenvolver o mencionado princípio da solidariedade.

Palavras-chave: princípio de solidariedade, responsabilidade do Estado, Conselho de Estado, conflito armado, ação de reparação direta, imputação, imputação objetiva, dano especial. 


\title{
Responsabilidad o solidaridad. El fundamento del deber de reparar en el ámbito de la responsabilidad extracontractual del Estado*
}

\author{
JULIÁN ANDRÉS PIMIENTO E. **
}

\begin{abstract}
SUMARIO
Introducción - I. USOS Y ABUSOS DEL CONCEPTO DE SOLIDARIDAD EN EL DERECHO NACIONAL - A. EI concepto de solidaridad en la jurisprudencia de la Corte Constitucional - 1. El papel de la solidaridad en el ordenamiento jurídico nacional - 2. Facetas o funciones de la solidaridad - a. Víctimas de la violencia (solidaridad/responsabilidad) - b. Progresividad del gasto social (solidaridad/progresividad) - c. Deber de solidaridad frente a los más vulnerables (solidaridad/auxilio). Art. 95.2 C. P. - B. La aplicación del principio de solidaridad en el ámbito de la responsabilidad del Estado. Aproximación teórica - 1. Solidaridad y elementos de la responsabilidad - a. Solidaridad y antijuridicidad del daño - b. Solidaridad e imputación - 2. La solidaridad como fundamento de la responsabilidad extracontractual del Estado en la jurisprudencia del Consejo de Estado - a. El principio de solidaridad como principio fundante de todo el sistema de responsabilidad pública - b. La solidaridad como fundamento de la responsabilidad del Estado en el marco de la violencia del país - II. EN BUSCA DEL FUNDAMENTO DEL DEBER DE REPARAR - A. La responsabilidad como fundamento del deber de reparar frente a la solidaridad como fundamento del deber de reparar - 1. El artículo 90 constitucional no se nutre del principio de solidaridad - 2. La desnaturalización del régimen de la responsabilidad extracontractual del Estado por la inadecuada aplicación del principio de solidaridad - B. Diferencias profundas entre uno y otro sistema - 1. En cuanto al fundamento normativo - 2. En cuanto al alcance de los poderes del juez - 3. En cuanto al alcance de la reparación - III. A MANERA DE CONCLUSIÓN. UNA CUESTIÓN DE PRINCIPIO: LA HIPERTROFIA DE LA RESPONSABILIDAD DEL ESTADO FUNDAMENTADA EN LA SOLIDARIDAD - Referencias.
\end{abstract}

* Cómo citar este artículo: Pimiento E., J. A. (Junio, 2016). Responsabilidad o solidaridad. El fundamento del deber de reparar en el ámbito de la responsabilidad extracontractual del Estado. Revista de Derecho Público, (36). Universidad de los Andes (Colombia). http://dx.doi.org/10.15425/redepub.36.2016.14

** Abogado de la Universidad Externado de Colombia. Doctor en Derecho Público por la Universidad París II, Panthéon-Assas. Magíster en Derecho Público Interno por la Universidad París II, Panthéon-Assas y titular de un DSU en Derecho Administrativo de la misma Universidad. Docente investigador de la Universidad Externado de Colombia. Ex magistrado auxiliar de la Sección Tercera del Consejo de Estado de Colombia. Correo: pimiento.julian@gmail.com.

El autor desea agradecer a Héctor Patiño y a Sergio Chemás, ambos de la Universidad Externado, por la lectura de los borradores de este artículo y por sus valiosos aportes.

Este artículo corresponde a la versión escrita de la ponencia presentada en las XVI Jornadas de Derecho Administrativo de la Universidad Externado de Colombia, en septiembre de 2015. 
Introducción

La responsabilidad del Estado ha sido secuestrada por el conflicto armado. No existe un ámbito de la materia que no haya visto su influjo al determinar las evoluciones recientes en esta área del derecho. ¿Cómo no justificar, desde el punto de vista de la responsabilidad, que el Estado es la causa y origen de todos los daños que por ello se produzcan? ¿Cómo no considerar que sea una tremenda injusticia que unos más que otros deban sufrir las incontables falencias de nuestro "Estado social de derecho"? Justicia, solidaridad, responsabilidad, todas se entrelazan y se mezclan cuando el drama de la sociedad entra en el escenario procesal. ¿Cómo no justificar que detrás de todo juez se encuentre un justiciero llamado a resolver, un caso a la vez, todos los problemas que nos aquejan y redistribuir, por esa vía, los avatares del infortunio? Al fin y al cabo, el juez, como todo ser humano, está llamado a ser solidario con aquellos menos afortunados, utilizando la única herramienta de la que dispone: la creación del derecho mediante su jurisprudencia.

La cuestión acerca del fundamento de la responsabilidad extracontractual no es, en lo absoluto, novedosa, desde antaño los juristas se han preocupado por justificar desde diversos puntos de vista la existencia de la obligación de reparar (Gil, 2011, p. 6). La cuestión se ha analizado desde diversos ángulos y con mayor o menor intensidad según las épocas, sin que se pueda considerar que existe, al menos en la actualidad, un consenso en torno a las bases filosóficas que soportan dicho deber. En todo caso, el debate se ha centrado tanto en los fundamentos como en las funciones del instituto de la responsabilidad.

Se evidencia, sin embargo, una constante en estos razonamientos: su relación con el principio de justicia (Coleman, 2010; Papayanis, 2013). Así, mientras se prueba la existencia de una estrecha relación entre la autonomía de la voluntad y la responsabilidad contractual, no aparece menos familiar la identidad que se reconoce entre una acepción concreta de justicia y el deber jurídico de reparar. Resulta claro, de cualquier manera, que a lo largo de la historia se ha intentado justificar, al menos filosóficamente, la obligación de reparar los daños causados en los principios de justicia -correctiva o distributiva-, de enriquecimiento sin causa, o aún en viejos aforismos como el de la obligación de reparar los daños injustamente causados -alterum non laedere-.

En el ámbito de la responsabilidad del Estado la cuestión ha sido un poco más complicada, puesto que su alcance y extensión depende del momento histórico en el que se construya la teoría. Para algunos, el derecho medieval estuvo ampliamente marcado por la ya consolidada idea del king can do no wrong propia del derecho inglés (Pareja, 1937, p. 198), y sin lugar a dudas expresiva del estado de la técnica jurídica en su tiempo, dado más a los aforismos que al análisis de la realidad, pues resulta evidente que existían ámbitos de responsabilidad del rey que aunque no tecnificados sí implicaban, por ejemplo, que el propio monarca se obligaba a respetar la propiedad privada en casos de 
expropiación o que por vía de declaraciones unilaterales (Santamaría, 1991, p. 116), ${ }^{1}$ se vinculara a respetar los derechos de algunas clases en particular.

Pero aparte de ese interesante debate históri$\mathrm{co}$, lo cierto es que la responsabilidad del Estado encontró su verdadero florecimiento desde el principio del siglo Xx y, principalmente, en la Europa occidental con la creación paulatina de las distintas categorías que le servirían de soporte: la tradicional falla del servicio y la excepcionalmente aplicada teoría del daño especial -cuyo título "teoría"- permitía entrever que más que una postura consolidada se trataba de un concepto en permanente construcción, cuyos límites eran, por decir lo menos, etéreos.

Los países europeos fueron adoptando con diferentes modelos un sistema de responsabilidad del Estado que reconoció las especificidades de esa Europa que vivió, en cien años, dos guerras mundiales, numerosas dictaduras, una profunda crisis económica, la revolución del conocimiento y la tecnología, así como un proceso de unificación permanente. Esas particularidades permitieron la consolidación de las figuras antedichas, a las que se agregó el ries- go excepcional. Cada país, a su manera, fue acercándose a los fenómenos sociales y mientras que los ordenamientos italiano (Leguina, 1983, p. 34) y español ${ }^{2}$ optaron por positivizar una determinada perspectiva en la materia, el derecho francés se mantuvo fiel a sí mismo, mediante la siempre expansiva creación judicial del derecho. ${ }^{3}$

El sistema colombiano, por su parte, es tributario de una realidad concreta. La violencia que se ha mantenido constante durante los últimos dos siglos -aunque con picos de intensidad demasiado notables- ha generado el decantamiento de un determinado modelo de responsabilidad del Estado. Desde el estricto positivismo, fueron los jueces los encargados de moldear una responsabilidad del Estado cercana a la del derecho francés, pero fue hasta 1991, con la entrada en vigor de la Constitución Política de ese año y, en particular, de su artículo 90, que se positivizó específicamente la responsabilidad del Estado, ${ }^{4}$ punto sobre el cual se volverá más adelante.

Desde el punto de vista procesal, resulta significativa la evolución de la institución de la acción de reparación directa reseñada por Alber-

1. Así como las referencias bibliográficas allí señaladas.

2. Cf. Sánchez (2010, p. 917 y ss.); García de Enterría y Fernández (2008, p. 361 y ss.); así como el esclarecedor texto de Mir Puigpelat (2012).

3. Cf. Gaudemet (2001, p. 803 y ss.), Chapus (2000, p. 1203 y ss.), con la excepción de la responsabilidad médica que fue desarrollada por un régimen legal. Ver, también, Truchet (2015, pp. 317-332).

4. En efecto, como lo afirma J. Carrillo Ballesteros, "la responsabilidad extrapatrimonial del Estado, responsabilidad administrativa; o responsabilidad patrimonial del Estado, pareció tener un nuevo aire con la Constitución de 1991 en cuyo artículo 90 se consagró expresa y normativamente, y por lo mismo con rango constitucional, el principio de la responsabilidad del Estado dentro del concepto de Estado Social de Derecho" (2001, pp. 87-104). 
to Montaña (2014, pp. 101-131), en la que se evidencia que no fue sino pasada la mitad del siglo XX que se unificó la competencia jurisdiccional en cabeza del Consejo de Estado (CE), para declarar comprometida la responsabilidad patrimonial de la Administración Pública y que fue esa sustantividad la que le dio vida a la institución más original -quizá- de nuestro derecho administrativo, pues es de estricta creación pretoriana, un modelo muy propio y avanzado de concreción de la responsabilidad patrimonial del Estado.

En cuanto al fondo, a lo sustancial de esa responsabilidad, desde principios del siglo XX se aplicó con vigor la doctrina francesa de la falla en el servicio, con diferentes alcances y matices, pero en lo relevante muy cercana al derecho francés. La teoría del daño especial hizo su aparición en 1946 con la sentencia del periódico El siglo S. A. (CE, sentencia del 27/07/1947), posteriormente ampliada y consolidada a partir de la responsabilidad del Estado por obras públicas; mientras que el último régimen en hacer su aparición fue el de riesgo excepcional a partir de la configuración de una pléyade de actividades riesgosas que en la actualidad justifican la aplicación de este régimen. ${ }^{5}$

Hoy existen alrededor de setenta actividades en las que se puede entender involucrada la responsabilidad del Estado - según el mismo Consejo de Estado-, Ilegando hasta los más recónditos aspectos de la actividad pública. Ello se explica por el carácter "hiperresponsabilista" de la práctica jurídico-administrativa colombiana, construida sobre las bases de un Estado que no siempre cumple los adjetivos que el constituyente le otorgó - puesto que no siempre es de derecho y rara vez es social-, aunado a una paradójica creencia en la institución judicial como mecanismo de imposición o redistribución de cargas estatales -no en vano la acción de tutela se ha convertido en el mecanismo estrella para hacer valer derechos públicos subjetivos ${ }^{6}$ - a lo que debe agregarse un papel activo de jueces y magistrados por corregir la situación de los habitantes del territorio tras cincuenta años de una guerra inclemente, aun a costa de los principios que sustentan la responsabilidad del Estado.

En este escenario y atendiendo a las transformaciones constantes que ha sufrido la responsabilidad del Estado colombiano desde sus inicios hasta la actualidad, cabe preguntarse por sus fundamentos, no solo porque tal ha sido el tema que me ha sido asignado, sino porque existen algunos cuestionamientos que, válidamente, se pueden esbozar en torno a su desarrollo actual por parte del juez de lo contencioso administrativo.

¿Se encuentra el fundamento del deber de reparar en la solidaridad -tal y como ha sido integrada en el artículo 1 C. P.- o bien existe

5. Al respecto, el completo estudio de Henao (1996, pp. 728-803).

6. En otro lugar se expusieron los riesgos inherentes a un sistema jurídico que, como el colombiano, se encuentra paradójicamente centrado en la actividad judicial como mecanismo de solución de cualquier conflicto social (Pimiento, 2014, pp. 350-373). 
una regla constitucional de la responsabilidad que justifica las condenas que se le imponen al Estado?

El tema se justifica plenamente al considerar el lugar que este debate ocupa en el derecho comparado, pero también -y principalmente- porque el uso de la solidaridad como fundamento del deber de reparar se hace más constante, en la medida en que desaparece, paulatinamente, el carácter eximente del hecho determinante de un tercero en la producción de un daño. En el presente artículo se intentará demostrar, mediante el análisis crítico de las posturas del Consejo de Estado y del soporte doctrinal en el cual se ha asentado, utilizando el método inductivo, que la solidaridad no puede ser válidamente concebida como el fundamento del deber de reparar en un juicio de responsabilidad del Estado. Para lo cual se abordará, en un primer momento, los usos y abusos del concepto de solidaridad en el derecho nacional $-\mathrm{y}$ en particular por parte de la Corte Constitucional- (I), para luego explicar de qué manera la utilización de la solidaridad como fundamento del deber de reparar desconoce los límites constitucionales de dicho principio (II) y, finalmente, aportar unas breves conclusiones derivadas de la investigación propuesta (III).

\section{USOS Y ABUSOS DEL CONCEPTO DE SOLIDARIDAD EN EL DERECHO NACIONAL}

La solidaridad se ha convertido en un avatar de la construcción jurídica de la responsabili- dad en el ordenamiento jurídico colombiano. Si partimos de la premisa -como lo hacemosde que la responsabilidad extracontractual del Estado se encuentra secuestrada por el conflicto armado, la solidaridad es, quizá, su arma más eficaz. En efecto, la mayoría de las referencias a dicho concepto en la jurisprudencia del Consejo de Estado se encuentran en el ámbito de la atribución de responsabilidad extracontractual a las entidades públicas, con ocasión de los daños producidos por actos terroristas perpetrados por terceros ajenos al Estado (B); sin embargo, para poder entender su dimensión normativa resulta necesario analizar los diferentes usos que la Corte Constitucional ha hecho de dicho concepto a partir de su concreción en la norma superior (A).

\section{A. El concepto de solidaridad en la jurisprudencia de la Corte Constitucional}

La jurisprudencia de la Corte Constitucional le ha atribuido al principio de solidaridad un papel concreto -fundacional, se podría decir-en la construcción del ordenamiento jurídico nacional (1), cuyo funcionamiento se precisa a partir de unas facetas que la propia Corte ha esbozado (2).

1. El papel de la solidaridad en el ordenamiento jurídico nacional

La solidaridad es, ante todo, en la jurisprudencia constitucional, un pilar fundamental del Es- 
tado de derecho, cuyo contenido y alcance se determina en cada caso concreto, como ocurre en general con todas las instituciones jurídicas.

Se puede identificar, en todo caso, que se le ha atribuido la característica de principio, en cuanto mandato de optimización que informa el gasto público social, la de derecho/deber y la de fundamento de la responsabilidad del Estado; en cada caso concreto su definición y alcance adquiere una dimensión distinta, aspecto que será tratado en el siguiente acápite; sin embargo, desde ya se puede afirmar que en la jurisprudencia de la Corte Constitucional, por tratarse de uno de los principios fundamentales del Estado social de derecho (Upegui, 2009, p. 76), ${ }^{7}$ la solidaridad tiene un carácter reforzado, pero dicho principio "no tiene por ello el carácter de absoluto", pues "no puede (...) llegar al extremo de eliminar la libertad individual y social a través de la materialización de Estado que, so pretexto de ejercer sus funciones de dirección de la economía, se transforma en uno totalitario" (CConst., C-1054/2004, M. Monroy).

Su definición, entonces,

como tercer pilar del Estado social de derecho (...) es un principio fundamental que apunta a las obligaciones que se imponen al Estado y a la sociedad frente a las personas que por razones individuales o estructurales, no están en condiciones de satisfacer de ma- nera autónoma sus requerimientos vitales. (CConst., C-793/2009, G. Mendoza).

En cuanto a su alcance, la Corte Constitucional ha señalado que

el principio de solidaridad implica el ejercicio de acciones o el desarrollo de actuaciones en beneficio de los demás y, en especial, del interés común que surge de la interrelación social del ser humano y representa la suma de intereses de la sociedad. (C-032/2008, M. Monroy).

Por ello mismo, como mandato de optimización, si bien el ordenamiento jurídico puede generar deberes concretos en materia de solidaridad que deben ser cumplidos por los particulares,

no puede en cambio hablarse de correlativos derechos subjetivos concretamente exigibles [cursivas añadidas] en materia de seguridad social, emanados directamente de tal principio constitucional. En este terreno, corresponde al legislador definir la manera concreta en la que el principio de solidaridad se desarrolla, como expresamente lo afirma el artículo 48 de la Carta (CConst., C-1054/2004, M. Cepeda);

en este sentido, la solidaridad puede ser limitada "siempre y cuando la limitación sea razonable y no resulte desproporcionada" (CConst.,

7. En lo que J. Upegui (2009, p. 76) ha definido como una de las doce tesis del Estado social de derecho constituidas en un haz de deberes constitucionales. 
C-1054/2004, M. Cepeda). En el caso concreto se trataba de una norma que buscaba promover la generación de empleo y la protección del empleo altamente calificado.

Así, para la Corte Constitucional, "este principio puede aplicarse de manera directa y constituye una importante herramienta de interpretación para la efectividad de los derechos individuales de las personas y de la colectividad en general" (CConst., C-032/2008, M. Monroy), por cuanto, tal y como lo afirmó la misma Corporación en sentencia posterior,

la solidaridad ha dejado de ser únicamente un precepto ético y reviste, en el Estado social de derecho, un valor hermenéutico de primer orden en cuanto a la sujeción de los particulares a la Constitución y a la ley (...) La solidaridad como modelo de conducta social permite al juez de tutela determinar la conformidad de las acciones $\mathrm{u}$ omisiones particulares según un referente objetivo, con miras a la protección efectiva de los derechos fundamentales. (CConst., T-810/2011, M. González). ${ }^{8}$

En ese sentido, resulta evidente, como lo concluyó la propia Corte Constitucional, que:

El principio de solidaridad cumple la función de corregir sistemáticamente algunos de los efectos nocivos que tienen las estructuras sociales y económicas sobre la convivencia política a largo plazo. Por supuesto, la solidaridad, como principio exigible a los particulares, no es un instrumento necesario para garantizar la convivencia política, independientemente del modelo de Estado. Se trata más bien de una construcción histórica, de una herramienta que acogió el Constituyente de 1991, como instrumento normativo consistente con su opción política por el Estado social de derecho. (T-810/2011, M. González).

2. Facetas o funciones de la solidaridad

Sin embargo, la Corte Constitucional ha determinado tres usos concretos, facetas o funciones de la solidaridad en el derecho nacional, porque la ha encontrado relacionada con los temas de víctimas de la violencia que aqueja al país (a), con asuntos relativos al gasto público social (b) y con el deber de auxilio respecto de las personas en situación de vulnerabilidad (c).

a. Víctimas de la violencia (solidaridad/responsabilidad)

Uno de los primeros usos que la Corte Constitucional le dio a la solidaridad se encuentra en la Sentencia C-197/93, en la cual analizó la constitucionalidad del Decreto-ley 444 de ese año, específicamente diseñado para asistir a las víctimas del terrorismo, y señaló que las

8. Postura reiterada en la Sentencia T-416/2013. 
medidas contempladas en dicho cuerpo normativo

se justifican política y jurídicamente, bajo la teoría que admite la responsabilidad estatal sin culpa, cuando el daño proviene de un riesgo de naturaleza excepcional y anormal, creado por la administración, como ocurre en la situación que nos ocupa, el cual es generado, con motivo del desarrollo de las actividades y misiones que el Estado debe asumir, para combatir la violencia y el terrorismo de la subversión guerrillera y del narcotráfico,

para posteriormente ligarlo a un deber fundamental de toda persona de "obrar conforme al principio de la solidaridad social, respondiendo con acciones humanitarias ante situaciones que pongan en peligro la vida o salud de las personas" que se encuentran en principio desligadas del conflicto armado pero que en atención a las necesidades del Estado son puestas en una situación de riesgo excepcional. En suma, este tipo de ayudas encuentran su fundamento en los principios de equidad y justicia distributiva "base y sustento del principio de igualdad ante las cargas públicas". Así, en esta perspectiva la ayuda a las víctimas del conflicto, para la Corte Constitucional, se sustenta tanto en el riesgo excepcional que sufren los habitantes del territorio como en el rompimiento del equilibrio de las cargas públicas, con un fundamento de equidad y justicia distributiva, aspectos íntimamente relaciona- dos con el principio/regla/deber ciudadano de solidaridad social, y por ello concluye: "Constituye un principio elemental de justicia que la reparación (...) sea asumida y distribuida entre todos los integrantes de la comunidad".

Las mismas consideraciones se aplican para los desplazados por la violencia, respecto de quienes la jurisprudencia de la Corte Constitucional ha extendido la protección contemplada en la Ley de Víctimas, argumentando no solo la igualdad que debe imperar en el diseño de dicho régimen, sino también el principio de solidaridad frente a aquellos que sufren ese flagelo (CConst., T-227/1997, A. Martínez). ${ }^{9}$

\section{b. Progresividad del gasto social (solidaridad/progresividad)}

En el ámbito de la seguridad social, la solidaridad es vista como un deber ciudadano que no solamente vincula al Estado -como una directiva de acción política (CConst., C-188/2006, R. Escobar)-, sino que determina la conducta de los particulares, a tal punto que el beneficio otorgado al Fondo de Previsión Social del Congreso de la República, consistente en la exención de participar en la subcuenta de compensación del Fondo de Solidaridad y Garantía constituye una violación al "principio de solidaridad” (CConst., C-017/1998, C. Gaviria). Similares consideraciones llevaron al Alto Tribunal Constitucional a considerar que la utilización

9. Ver, también, Corte Constitucional, sentencias C-232/2002 y SU-1150/2000. 
de la institución de la parafiscalidad es una "aplicación concreta del principio de solidaridad, que revierte en el desarrollo y fomento de determinadas actividades consideradas como de interés general" (CConst., C-678/1998, A. Beltrán) $\cdot{ }^{10}$ En este sentido, el principio de solidaridad se considera como un mecanismo de "socialización de los riesgos inherentes a la vida” (CConst., C-1054/2004). ${ }^{11}$

En idéntica dirección, en un asunto en el que se cuestionaba la constitucionalidad de la ley aprobatoria del Presupuesto General de la Nación por la omisión del legislador de no incluir una partida presupuestal suficiente para aumentar el salario de algunos trabajadores del Estado, la Corte Constitucional, para declarar la constitucionalidad de la norma demandada, concluyó que

en virtud del principio de solidaridad, quienes están mejor en la sociedad son los llamados a colaborar con aquellos que se encuentran en estado de vulnerabilidad, situación de indefensión o desprotección, o en estado de marginación. En este caso, considera la Car- ta que no es desproporcionado limitar a los servidores públicos con mejores salarios el derecho a mantener el poder adquisitivo real de su salario, con el fin de liberar y destinar recursos a cubrir las necesidades relativas al gasto público social. (CConst., C-1064/2001, M. Cepeda),

lo que justificaba, en su criterio, que "quienes tengan más capacidad contributiva, aporten en proporciones mayores" (CConst., C-1064/2001). ${ }^{12}$

Consideró, además, la Corte Constitucional, que el régimen pensional de ahorro individual "desarrolla cabalmente el principio de solidaridad, porque en este subsistema se da la práctica de la mutua ayuda entre las personas, las generaciones, los sectores económicos y las comunidades, bajo la protección del más fuerte hacia el más débil" (C-086/2002, C. Vargas). Razonamiento similar se encuentra, para la Corte Constitucional, en el fundamento del cobro tarifario por expansión de redes contemplado en la legislación de servicios públicos domiciliarios (C- 532/2005, M.

10. Citando a Corte Constitucional, Sentencia C-040/1993.

11. En el caso concreto, la cuestión se contraía a determinar si el hecho de que existiera un ingreso base de cotización, diferenciado atendiendo el monto de los ingresos, violaba los principios constitucionales que informan el sistema de seguridad social en pensiones.

12. El grado de concreción de tal principio fundante del sistema de seguridad social -en salud o en pensiones-es evidente, pues para la Corte Constitucional, "el principio de solidaridad en materia pensional se concreta así: en el régimen de prima media con prestación definida, el 10.5\% del ingreso base de cotización se destina a financiar la pensión de vejez y la constitución de reservas para tal efecto. El 3\% restante sobre el ingreso base de cotización se destina a financiar los gastos de administración y la pensión de invalidez y sobrevivientes. En el régimen de ahorro individual con solidaridad, el 10\% del ingreso base de cotización se destina a las cuentas individuales de ahorro pensional. Un 0.5\% del ingreso base de cotización se destina al Fondo de Garantía de Pensión Mínima del Régimen de Ahorro Individual con Solidaridad, y el 3\% restante se dirige a financiar los gastos de administración, la prima de reaseguros de Fogafín, y las primas de los seguros de invalidez y sobrevivientes", es decir, se trata de un principio que integra todo el sistema y que lo dirige. 
Cepeda) ${ }^{13}$ en la medida en que el acceso a dichos servicios sea pagado según la capacidad económica de los usuarios, ${ }^{14}$ aplicando para ello un criterio de justicia distributiva.

Existe, entonces, en el ordenamiento jurídico nacional, en materia de gasto público social, un concepto normativo de solidaridad que en igual medida se ha decantado por el principio en estudio en el ámbito de la seguridad social en salud. ${ }^{15}$

\section{c. Deber de solidaridad frente} a los más vulnerables (solidaridad/auxilio). Art. 95.2 C. P.

En criterio de la Corte Constitucional, la solidaridad como valor fundante - se ha hecho, en este sentido, referencia concretamente a un modelo ético constitucional- del Estado colombiano es un concepto multiforme que se expresa de varias maneras, entre otras:

(i) la que le corresponde asumir al Estado, a la sociedad y a la familia frente al derecho a la vida digna; (ii) la que le atañe a las personas frente al deber de contribuir al financiamiento de los gastos e inversiones del Estado dentro de conceptos de justicia y equidad; (iii) la que le corresponde al empleador frente a la dignidad del trabajador que padece de alguna enfermedad catastrófica, manteniéndolo en su cargo, o si existe posibilidad de contagio, reubicándolo en otra plaza. (C594/2004, M. Cepeda).

Como se observa, el asunto ha trascendido el análisis de su contenido en los juicios de constitucionalidad hasta los deberes propios de las

13. Aplicable igualmente en servicios públicos sociales como el de educación.

14. Así, “la Corte estima que el cobro de un factor tarifario por concepto de costos de expansión no puede ser asumido por todos los usuarios independientemente de cuál sea su capacidad económica, pues ello implicaría una vulneración del principio de solidaridad en el ámbito de los servicios públicos" (CConst., C-150/2003, M. Cepeda), lo cual reitera en muchos aspectos lo afirmado en su Sentencia C-517/1992.

15. En las sentencias T-1000/2007 y C-313/2014, la Corte Constitucional afirmó: "Así mismo, en relación con la aplicación del principio de solidaridad en materia de seguridad social, la Corte ha considerado que (i) este permite que el derecho a la seguridad social se realice, si es necesario, a través de la exigencia de prestaciones adicionales por parte de las entidades que han cumplido con todas sus obligaciones prestacionales, conforme a lo establecido en las leyes (...) el principio aludido también impone un compromiso sustancial del Estado en cualquiera de sus niveles (Nación, departamento, municipio), así como de los empleadores públicos y privados en la protección efectiva de los derechos fundamentales de los trabajadores y de sus familias; (ii) implica que todos los partícipes de este sistema deben contribuir a su sostenibilidad, equidad y eficiencia, lo cual explica que sus miembros deban en general cotizar, no solo para poder recibir los distintos beneficios, sino además para preservar el sistema en su conjunto; (iii) la ley puede, dentro de determinados límites, estructurar la forma como los distintos agentes deben cumplir con su deber de solidaridad; (iv) los aportes deben ser fijados de conformidad con criterios de progresividad, que permitan que quienes más capacidad contributiva tengan, aporten en proporciones mayores; ( $v$ ) si bien es uno de aquellos considerados fundamentales por el primer artículo de la Constitución, no tiene por ello un carácter absoluto, ilimitado, ni superior frente a los demás que definen el perfil del Estado social de derecho, sino que la eficacia jurídica de otros valores, principios y objetivos constitucionales puede acarrear su restricción, mas no su eliminación; (vi) conforme a lo prescrito por el artículo 95 superior, el principio de solidaridad genera deberes concretos en cabeza de las personas, no puede en cambio hablarse de correlativos derechos subjetivos concretamente exigibles en materia de seguridad social, emanados directamente de tal principio constitucional; (vii) no es tan amplio el principio de solidaridad social dispuesto en nuestra Carta Política, como para suponer en toda persona el deber de responder con acciones humanitarias, sin límite al- 
autoridades y los ciudadanos frente al Estado y en sus relaciones con otros particulares, en el Estado social de derecho. Así, en un caso en el que se discutía la violación de los derechos fundamentales por falencias en el cuidado de una menor de edad que aparentemente podía constituir un caso de abuso sexual, la Corte Constitucional discurrió ampliamente acerca de este principio, para señalar en Sentencia T-389/1999 (C. Gaviria) que "si los particulares no cumplen con sus deberes, si no colaboran con su parte dentro del delicado y complejo entramado social, la búsqueda de fines colectivos es inútil, la consecución del bienestar comunitario o individual no es posible", por ello la postulación de este principio "no tiene otro objetivo que recordar junto a la necesidad de colaboración entre los miembros que componen un mismo cuerpo".

En el caso de un paciente a quien a pesar de habérsele diagnosticado VIH se le negó la prestación del servicio de salud, el Alto Tribunal perfiló el principio de solidaridad como un deber “impuesto a toda persona por el solo hecho de su pertenencia al conglomerado social, consistente en la vinculación del propio esfuerzo y actividad en beneficio o apoyo de otros asociados o en interés colectivo" (CConst., T-550/1994, J. Hernández), por lo tanto, según la jurisprudencia que la misma Corporación decantó:

Son tres las manifestaciones del principio de solidaridad social: (i) como una pauta de comportamiento conforme a la cual deben obrar los individuos en ciertas situaciones, (ii) un criterio de interpretación en el análisis de acciones $u$ omisiones de los particulares que vulneren o amenacen vulnerar derechos fundamentales y (iii) un límite a los derechos propios. (CConst., T-434/2002, R. Escobar).

Bueno es precisar que en este tipo de eventos, en el caso de la solidaridad-auxilio, la jurisprudencia señala tres niveles distintos de procedencia del principio de solidaridad en temas ligados a la salud: en primer lugar se encuentra el mismo afectado, luego su familia (CConst., T-046/2005, C. Vargas) y, finalmente, ${ }^{16}$ de manera subsidiaria, ante la imposibilidad de los otros dos de cumplir

guno, ante situaciones que pongan en peligro su vida o la salud de los demás; (viii) exige la ayuda mutua entre las personas afiliadas, vinculadas y beneficiarias, independientemente del sector económico al cual pertenezcan, y sin importar el estricto orden generacional en el cual se encuentren; (ix) implica las reglas según las cuales el deber de los sectores con mayores recursos económicos de contribuir al financiamiento de la seguridad social de las personas de escasos ingresos, y la obligación de la sociedad entera o de alguna parte de ella, de colaborar en la protección de la seguridad social de las personas que por diversas circunstancias están imposibilitadas para procurarse su propio sustento y el de su familia; $\mathrm{y}$ ( $\mathrm{x}$ ) se pueden aumentar razonablemente las tasas de cotización, siempre y cuando no vulneren los derechos fundamentales al mínimo vital y a la vida digna."

16. En efecto, "de acuerdo con las previsiones constitucionales, el deber de cuidar y proteger la salud se predica en primera medida del aquejado y, subsidiariamente, 'le corresponderá atenderlo a la familia, pero solo cuando hay una palpable indefensión para el enfermo, y, con fundamento en el artículo 5 de la C.P, a falta de esta, será el Estado y la sociedad quienes acudirán a la defensa del impedido'" y concluye: "Se encuentra acorde con el principio de supervivencia y autoconservación, el que sea el enfermo el primer interesado en procurarse los cuidados pertinentes para recuperar la salud. No obstante, si este se halla en imposibilidad de hacerlo, le corresponde a la familia proporcionarle la atención necesaria y, a falta de esta, es deber de la sociedad y el Estado concurrir a su protección y ayuda" (CConst., T-434/2002, R. escobar). En idéntica dirección se enfoca la Sentencia T-046/2005. 
satisfactoriamente ese deber, le corresponderá asumir dicha carga al Estado. ${ }^{17}$

Así mismo, la solidaridad impregna la defensa por parte de los particulares de los derechos colectivos, lo que justificaba, a nivel constitucional, la existencia de un incentivo para quienes interpusieran acciones populares, como un mecanismo para suscitar la solidaridad entre los habitantes del país en la protección de lo colectivo (CConst., C-594/2004, M. Cepeda). ${ }^{18}$ Deber de solidaridad que también resulta exigible de las entidades financieras en casos en que exista imposibilidad material de cumplir con una obligación crediticia ${ }^{19}$ o que el deudor se encuentre en condiciones de vulnerabilidad particulares, y exigible aún a los patronos en el ámbito de las relaciones laborales, tal y como lo ha indicado la Corte Constitucional (T-520/2003, R. Escobar). ${ }^{20}$ Y que inspira, además, instituciones de diversa naturaleza como el delito de omisión de socorro (CConst., C-003/2005, J. Córdoba), el deber de denuncia (CConst., C-818/2014, M. Sáchica) o aún cuestiones tan disímiles de esas como la prohibición de la publicidad y promoción de productos de tabaco (CConst., C-830/2010, L. Vargas), la agencia oficiosa en el ámbito del derecho procesal (CConst., T-031A, 2011, N. Pinilla), la judicatura ad honorem (CConst., T-932/2012,
M. Calle) o las limitaciones a la libertad de escogencia de profesión, derivadas de los requisitos para acceder a los títulos profesionales o técnicos (CConst., C-166/2015, G. Ortiz).

\section{B. La aplicación del principio de solidaridad en el ámbito de la responsabilidad del Estado. Aproximación teórica}

Siguiendo las reflexiones que anteceden, no existe duda de que la solidaridad adquiere un especial valor en el derecho colombiano. Se trata de una figura multifacética que tiene diversas acepciones, pero principalmente un conjunto de usos y funciones diversos que le otorgan el carácter de comodín o de justificación común de variadas herramientas jurídicas. Así, la solidaridad funge como un valor fundante del Estado colombiano, como uno de los pilares del Estado social de derecho -junto con el respeto a la dignidad humana y el trabajo-, como un principio -mandato de optimización de la conducta de las autoridades públicas y de los particulares-, como un deber de inmediato cumplimiento, así como un derecho exigible de los particulares y del Estado; finalmente ha servido, también, como fundamento de algunas hipótesis de reparación de víctimas.

17. Para la Corte Constitucional, entonces "es claro que sólo ante la falta de recursos económicos del actor o de su familia, le corresponde al Estado asumir su asistencia” (T-710/2010, J. Palacio), postura reiterada en los mismos términos en la Sentencia T-413/2013.

18. Cf., también, Corte Constitucional, Sentencia C-630/2011.

19. En el caso de desplazados, por ejemplo, ver Corte Constitucional, Sentencia T-207/2012.

20. Corte Constitucional, sentencias T-419/2004, T-170/2005, T-777/2011 y T-341/2012, entre muchas otras. 0 como en el caso del fuero de maternidad como expresión del principio de solidaridad (Sentencia T-088/2010, J. Pretelt). 
Existen, sin embargo, unos usos propios del principio de solidaridad en el ámbito de la responsabilidad patrimonial de la Administración Pública, generados por el propio Consejo de Estado en la construcción de su jurisprudencia. Los usos a los que se hace referencia tienen que ver con los elementos de la responsabilidad (1) o con el fundamento mismo de la responsabilidad (2).

1. Solidaridad y elementos de la responsabilidad

El Consejo de Estado, en algunas ocasiones y de manera concreta, ha utilizado el principio/ deber de solidaridad para identificar la antijuridicidad del daño (a), o como fundamento de su imputación (b). Frente a ello, la doctrina también aporta unos elementos concretos de identificación de los usos de dicho principio/deber en el ámbito de la responsabilidad del Estado.

\section{a. Solidaridad y antijuridicidad del daño}

En dos ocasiones, pero con seguridad se pueden evidenciar algunas más entre las líneas de la jurisprudencia del Consejo de Estado, se ha utilizado la solidaridad como elemento de necesaria presencia en la determinación de la antijuridicidad del daño.

No existe duda alguna, a manera de precisión previa, de que el concepto de daño antijurídi- co es el que más dificultades presenta en los juicios de responsabilidad, principalmente porque desde su concepción inicial adoleció de la concreción necesaria para cumplir el papel central que se le otorgó en la construcción de la responsabilidad civil extracontractual. No se prestará aquí demasiada atención al concepto, por exceder -al menos en parte- los tres objetivos del tema planteado, baste decir por ahora que en el derecho nacional se ha repetido sin mucho debate ni reflexión lo que se ha dicho en el derecho español acerca de la necesaria antijuridicidad del daño resarcible en los juicios de responsabilidad, al considerar lo que ya es un lugar común, que el artículo 90 de la Constitución Política trasladó el énfasis de la conducta del agente causante del daño al sujeto que lo recibe en su patrimonio, despejando del análisis la necesaria verificación de la culpa del ámbito de la responsabilidad patrimonial del Estado; no quiere ello decir que se excluya, sino simplemente que es un criterio verificable pero no necesario para declarar comprometida dicha responsabilidad.

Igualmente, se ha repetido hasta la saciedad que el daño antijurídico es, como lo formularan tradicionalmente García de Enterría y Fernández (2008), la lesión a un patrimonio que no se está en el deber jurídico de soportar. ${ }^{21} \mathrm{Ob}$ viamente que una definición tan amplia, omnicomprensiva y universalista debía ser concretada de alguna manera, pero dicho papel le correspondería al legislador en primera medida -los daños expresamente avalados por la 
ley (impuestos, modificación de condiciones generales del ejercicio de una actividad económica y, en general, el ejercicio de la reglamentación general del Estado) no podrían ser considerados como antijurídicos-, y al juez en la resolución de los casos concretos.

Queda, sin embargo, una duda global en torno a la abstracción del concepto o, mejor, a su carácter genérico que sirve de justificación para el arbitrio del juez, mas no para fundamentar de manera adecuada la responsabilidad del Estado. Ello se evidencia claramente en la confusión que puede existir y de hecho existe en el alcance del daño antijurídico como elemento determinante de la responsabilidad patrimonial y la imputación, máxime si se tiene en cuenta que para García de Enterría y Fernández (2008) la antijuridicidad del daño es una cuestión de imputación. ${ }^{22}$

En cualquier caso, el Consejo de Estado, por ejemplo, consideró que el daño antijurídico es aquel que "se encuadra en los principios consagrados en la Constitución, tales como la solidaridad (Art. $1^{\circ}$ ) y la igualdad (Art. 13), y en la garantía integral del patrimonio de los ciudadanos, prevista por los artículos $2^{\circ}$ y 58 de la Constitución", citando para ello la jurispruden- cia de la Corte Constitucional, ${ }^{23}$ para concluir que el daño antijurídico

es un concepto que es constante en la jurisprudencia del Consejo Estado, que debe ser objeto de adecuación y actualización a la luz de los principios del Estado Social de Derecho, ya que como lo señala el precedente de la Sala un 'Estado Social de Derecho y solidario y respetuoso de la dignidad de la persona humana, no puede causar daños antijurídicos y no indemnizarlos'. (CE, Sección Tercera, Subsección C, exp. 19195, 31/08/11).

Más allá de la evidente confusión en la que incurre el fallo al confundir daño con daño antijurídico -error constante y corriente en la jurisprudencia del Alto Tribunal-,${ }^{24}$ resulta interesante resaltar que la solidaridad funge de elemento determinante de dicha antijuridicidad, es decir, el principio en comento dirige y determina la obligación misma del deber de reparar, pero ello se confunde, en el precedente en cita, con el juicio de imputación.

\section{b. Solidaridad e imputación}

Normativamente, según el artículo 90 constitucional, el Estado debe resarcir los daños an-

22. Punto sobre el que se volverá más adelante. Cf. García de Enterría y Fernández (2008, p. 367).

23. En particular las sentencias de la Corte Constitucional C-333/1996 y C-832/2001.

24. Identificado también por M'Causland, quien con rigor señala: “Mientras el daño antijurídico alude a aquellas afectaciones negativas sufridas por una persona que no está en el deber jurídico de soportarlas, porque ninguna norma se lo impone, y constituye un elemento estructural de la responsabilidad en cualquiera de los regímenes - subjetivos y objetivos- que permiten fundarla, el daño especial constituye un elemento particular del régimen identificado con el mismo nombre y supone que una persona o un grupo de personas sufre una afectación como consecuencia de una acción u omisión lícita del Estado, cuyo fin es el beneficio de la comunidad en general" (2013, pp. 548 y 549). 
tijurídicos causados por conductas -activas u omisivas- que le sean imputables. Son dos, entonces, los elementos constitucionales que se deben estudiar en un juicio de responsabilidad, o tres según las diferentes teorías que se han decantado en la doctrina nacional; ${ }^{25}$ lo cierto es que, más allá de ese interesante debate y de lo que se deba incluir en el contenido de dichos elementos de la responsabilidad, el juicio de imputación es un ejercicio necesario para determinar la configuración de la mencionada responsabilidad. Para parafrasear al rector Juan Carlos Henao (1996), la verificación del daño -antjurídico, aquí- es el primer elemento de la responsabilidad, necesario, pero no suficiente, pues el daño -ahora sí, solodebe poder imputarse a una entidad pública o a un particular que ejerza funciones administrativas. Dicha relación estrecha y simbiótica para los efectos aquí descritos entre daño, su antijuridicidad y su imputación, ha generado incontables confusiones en la doctrina y en la jurisprudencia.

Baste demostrar, por ahora, que el principio de solidaridad también ha irrumpido en el juicio de imputación.

Existe una constante, por ejemplo, en algunas sentencias de las distintas subsecciones que componen la Sección Tercera del Consejo de Estado, en considerar que el fundamento del daño especial es el principio de solidaridad. Así, por ejemplo, en sentencia de $2011^{26}$ afirmó que

instrumentalizar el daño especial como criterio de imputación en el presente caso, implica la realización de un análisis que acorde con el art. 90 Const., tome como punto de partida el daño antijurídico que sufrieron los demandantes; que se asuma que el daño causado, desde un punto de vista jurídico y no simplemente de las leyes causales de la naturaleza, se debe entender como fruto de la actividad lícita del Estado; y, que, por consiguiente, concluya que es tarea de éste, con fundamento en el principio de solidaridad interpretado dentro del contexto del Estado social de derecho, equilibrar nuevamente las cargas que como fruto de su actividad, soporta en forma excesiva uno de sus asociados, alcanzando así una concreción real el principio de igualdad. (CE, Sección Tercera, Subsección C, exp. 20835, 7/07/11).

De esta manera la imputación, como escenario en el que se debe determinar el régimen de responsabilidad, justifica la aplicación del daño especial, entendido este como el deber

25. Al respecto ver el interesante análisis que realizó Patiño (2015, pp. 165 a 180).

26. Sin embargo, esa postura no es del todo novedosa, pues hizo parte del acervo argumentativo del Consejo de Estado mucho antes de la entrada en vigencia de la Constitución Política de 1991; al respecto, M'Causland (2013) da cuenta de un fallo del 23 de mayo de 1973, exp. 973, en el que se afirmó: “Es evidente que, por lo menos, por razones de equidad y de justicia distributiva quien ha sufrido un perjuicio causado por la Administración debe ser indemnizado, y ciertamente en el caso de autos la señora Vitalia V. de Pinilla, no tiene por qué sufrir ella sola los daños producidos por un acto de la administración, legítimo desde luego, al cual fue tan extraña como cualquier ciudadano". También se referencia, con razonamientos muy similares, la sentencia del 28 de octubre de 1976, exp. 1567 de 2013, p. 526. 
de reequilibrar las cargas públicas que se habían desajustado con ocasión de la actividad estatal, todo ello con fundamento en el principio de solidaridad.

En igual dirección consideró que el daño especial es un régimen

fundamentado en la equidad y la solidaridad, en el que se reparan los daños que tienen la característica de ser anormales y excepcionales, y que los ciudadanos no tienen la obligación de soportar en cuanto se les impone una carga desigual. (CE, Sección Tercera, Subsección C, exp. 28644, 12/06/14).

Aquí se invierte en cualquier caso el análisis, pues -como también lo afirmó el Consejo de Estado, pero en distinta subsección-, la finalidad de la imputación en el caso del daño especial consiste en determinar "si la no reparación del perjuicio causado llegaría a configurar un atentado directo contra los principios constitucionales de justicia, solidaridad y equidad" (CE, Sección Tercera, Subsección A, exp. 29338, 26/02/15). Resulta palmaria, entonces, la confusión entre imputación -atribución de determinada conducta originaria de un daño-y la antijuridicidad del daño - entendida esta como la atribución de la obligación de soportar el daño a un sujeto distinto de quien lo sufre-.
Lo cierto, sin embargo, es que en la jurisprudencia del Consejo de Estado, el fundamento del daño especial parece desligarse de fundamentos causales - de imputación en estricto sentido- para ubicarse en conceptos normativos más amplios. Lo que transpira de esos razonamientos es que el deber de reparar en el caso del daño especial brota de un imperativo de justicia distributiva, no de la responsabilidad por los daños causados sino de la particular situación del demandante al que no se le puede dejar inerme ante la conducta legítima del Estado; al parecer ello se corresponde con una particular forma de ver el ejercicio del juez como un agente que busca corregir lo que podríamos llamar daños colaterales de la actividad administrativa.

Pero en este razonamiento se confunden equidad -o lo que vendría a ser lo mismo para esos efectos, igualdad-y solidaridad. ${ }^{27}$ En este sentido, resulta diciente que la Sección Tercera, Subsección A, haya afirmado sin ambages en el exp. 29338 de 26/02/15, que "la teoría del daño especial tiene su fundamento en la equidad" y concluya sin matices afirmando que dicha teoría "sólo resulta aplicable a eventos que, de analizarse a la luz de los regímenes comunes de responsabilidad, culminarían en un fallo absolutorio, pero, a la vez, notoriamente inicuo", pero que sustente su afirmación en

27. En efecto, en casos de daño especial, se debe "declarar la existencia de responsabilidad estatal en cabeza de la demandada, por cuanto la obligación indemnizatoria que se deduce, proviene del imperativo de protección de la víctima en aplicación de los principios de justicia y equidad y, por cuanto para la víctima injustamente afectada, el daño irrogado entrañó un claro rompimiento de las cargas públicas que normalmente debían soportar" (CE, Sección Tercera, Subsección A, exp. 29338, 26/02/15). 
una sentencia de 2007 , en la que ella misma razonó:

Esta reparación igualitaria, en cuanto responsabilidad del Estado, es reforzada en su razón de ser por la solidaridad, valor que debe animar el actuar del Estado colombiano, no sólo por su calidad de Social y por ende redistributivo sino además porque el constituyente ratificó este carácter al consagrar en el art. $1^{\circ}$ a la solidaridad como uno de los valores fundantes del Estado. (CE, Sección Tercera, exp. 16696, 3/05/07).

2. La solidaridad como fundamento de la responsabilidad extracontractual del Estado en la jurisprudencia del Consejo de Estado

El Consejo de Estado ha utilizado el principio/ derecho/deber de solidaridad como fundamento de la responsabilidad del Estado en diversas ocasiones, contribuyendo a generar confusión en el fundamento del deber de reparar derivado de la causación de daños.

a. El principio de solidaridad como principio fundante de todo el sistema de responsabilidad pública

En un primer momento, la jurisprudencia consideró que los regímenes objetivos de responsabilidad, es decir, la responsabilidad sin falta o sin culpa, se fundamentaban en el principio de solidaridad. Así, en sentencia de 1992, la Sección Tercera del Consejo de Estado, afirmó: “Es posible, en muchos casos, que se tenga derecho a la indemnización de los daños patrimoniales ocasionados con una actuación administrativa lícita. La filosofía que informa todo este universo jurídico se apoya en EL PRINCIPIO DE SOLIDARIDAD" (exp. 6784, 22/11/91). [Mayúsculas en el original]. En el caso concreto, las pretensiones versaban sobre la responsabilidad patrimonial que podría incumbir a la entidad pública demandada por los daños irrogados con ocasión de la construcción de un talud.

De manera general, dicho razonamiento se encuentra reiterado en idénticos términos en numerosos pronunciamientos de la época; todos ellos tuvieron en común al mismo ponente: el consejero Julio César Uribe Acosta. Con base en ese fundamento, por ejemplo, se condenó al Estado por los perjuicios sufridos en un inmueble de propiedad del demandante al no haberse acreditado que la conflagración había ocurrido por una causa extraña (CE, Sección Tercera, exp. 7130, 26/11/92), o bien por la electrocución de un operario de maquinaria pesada a quien no se le había proporcionado el entrenamiento adecuado (CE, Sección Tercera, exp. 7217, 30/07/92), o los perjuicios ocasionados en un predio de una persona por el rompimiento del canal del dique en el Atlántico (CE, Sección Tercera, exp. 6784, 22/11/91). ${ }^{28}$

28. En la especie se acreditó la falla del servicio en el mantenimiento de dicha obra pública, pero ello no incidió en el razonamiento de la Sección Tercera en aquella oportunidad pues "para la Sala esa perspectiva de manejo probatorio no es de recibo en el caso en comento, pues como ya se dijo en otro aparte de esta providencia, la culpa del centro de imputación jurídica 
En esta visión omnicomprensiva, entonces, la responsabilidad del Estado, bajo el en ese entonces novedoso régimen constitucional, sería una expresión más del principio de solidaridad; en ese escenario extremadamente amplio no cabe más que concluir, al menos desde el punto de vista teórico, que el Estado sería responsable por todos los daños que se pudieren producir al interior suyo, como una especie de garante universal.

\section{b. La solidaridad como fundamento de la responsabilidad del Estado en el marco de la violencia del país}

Probablemente el puente entre la solidaridad, por un lado, como fundamento global del artículo 90 y, por otro, como basamento de la responsabilidad del Estado por atentados terroristas, se encuentra en una sentencia del mismo ponente que las reseñadas en el acápite inmediatamente anterior, el Dr. Julio César Uribe Acosta, en la que se condenó al Estado por los perjuicios sufridos con ocasión de la explosión del carro bomba al frente de las instalaciones del antiguo Departamento Administrativo de Seguridad (DAS), detonado con la intención de atacar al entonces director de dicha entidad; en tal fallo, luego de largas disquisiciones en torno a la responsabilidad del Estado, se afirmó que la solidaridad se encontraba en la base de todo este sistema normativo, pero además se indicó que

la solidaridad, finalmente, demanda de cada una de las personas un altruismo universal, para no ver a los semejantes sólo como miembros de un determinado grupo secta [sic], y un altruismo peligroso, para tener el valor de sacrificar la vida y los bienes por los que están en grave riesgo de perderlo todo. (CE, Sección Tercera, exp. 8577, 23/09/94).

Desde 2007, en un caso que se caracteriza por una situación particularmente delicada, en la que una menor de edad sufrió unos perjuicios derivados de la explosión de una granada que fue lanzada por unos delincuentes contra la policía en el marco de una persecución policial, pero que por accidente cayó en la casa donde se encontraba la víctima directa, se tomó un rumbo decidido hacia el reconocimiento de la solidaridad como fundamento del deber de reparar atribuido al Estado. En esa ocasión, con la finalidad de romper la causal eximente de la responsabilidad tipificada como el hecho de un tercero, se consideró que el régimen de res-

demandado resultó bien probada. Pero es más: Si la realidad probatoria hubiese sido otra, debe recordarse que a la luz de lo preceptuado en el artículo 90 de la Constitución Nacional de 1991, el Estado debe responder '... patrimonialmente por los daños antijurídicos que le sean imputables, causados por la acción o la omisión de las autoridades públicas'. Dentro de este universo constitucional no hay duda de que el fundamento de la responsabilidad administrativa no se da siempre por una conducta dolosa o culpable, que deba ser sancionada, sino por el quebranto patrimonial que hay que reparar. La atención del constituyente se desplazó, pues, desde el autor a la conducta causante del daño, hacia la víctima misma. Por ello importa más reparar el daño causado, que castigar una acción u omisión administrativa culpable. La finalidad de la responsabilidad patrimonial no consiste, pues, en BORRAR UNA CULPA, sino en hacer recaer sobre el patrimonio de la administración, el DAÑO SUFRIDO por el particular." 
ponsabilidad aplicable era el de daño especial, cuyo sustento se encuentra en el principio de solidaridad -considerar lo contrario llevaría a una sentencia inicua o contraria al principio de justicia material, distributiva, según las consideraciones del operador judicial-, pero que dicha situación se debía atribuir plenamente a las autoridades públicas en la medida en que el contexto en el que ocurrieron los hechos había sido causado por el propio Estado, es decir, la granada se lanzó con el fin de repeler la persecución policial (CE, Sección Tercera, exp. 16696, 3/05/07).

Sin embargo, no fue sino hasta 2011 (CE, Sección Tercera, Subsección C, exp. 20835, 7/07/11) que la Sección Tercera, esta vez por la vía de sus subsecciones, presentó argumentos específicos en cuanto al basamento de la responsabilidad del Estado en el principio de solidaridad. En el caso concreto, se buscaba la declaratoria de responsabilidad patrimonial de la Policía Nacional por los perjuicios que le fueron ocasionados a un transeúnte que resultó herido por la explosión de una bomba con la que se quería afectar un Centro de Atención Inmediata (CAI). En esa ocasión afirmó:

El acervo probatorio aporta seguridad inconcusa sobre la intención de los autores del acto terrorista: atacar a la Policía Nacional y a la institucionalidad que representa, esto es, al Estado (...) Esta teoría, con fuerte ba- samento en la equidad y la solidaridad, se enmarca dentro de los factores objetivos de imputación de responsabilidad estatal con los que se ha enriquecido este catálogo. (CE, Sección Tercera, Subsección C, exp. 20835, 7/07/11).

Frente a lo que concluye que

en cuanto el acto terrorista se dirige contra la sociedad en su conjunto, pero se localiza materialmente en el perjuicio excepcional y anormal respecto de un ciudadano o grupo de ciudadanos muy reducido, será toda la sociedad la que soporte, de forma equitativa, esa carga. (CE, Sección Tercera, Subsección C, exp. 20835, 7/07/11).

Se trata, en el fondo, de la socialización de los riesgos inherentes a la vida en comunidad.

En otras sentencias de la misma Subsección C se acogen de manera directa y sin ambages las posturas propias de alguna teoría del derecho penal, para objetivizar ya no los regímenes de responsabilidad, sino los elementos propios de ella, es decir, adopta sin límites la teoría de la imputación objetiva ${ }^{29}$-de cariz estrictamente normativo- y en cuanto existe una obligación concreta de evitar un resultado, se objetiviza el daño antijurídico. Al respecto resultan tan dicientes como preocupantes las siguientes afirmaciones:

29. Es de resaltar que, para el autor de este artículo, en la doctrina de algunas subsecciones que componen la Sección Tercera se realiza un uso inadecuado de la teoría de la imputación objetiva, traída sin mayor adecuación de alguna escuela del derecho penal, con lo cual se ha desnaturalizado el juicio de responsabilidad del Estado en el marco que contempla el artículo 90 constitucional. 
Es imputable la responsabilidad patrimonial a las entidades demandadas, pese a que en los hechos haya intervenido un tercero (grupo armado insurgente), ya que no fue esta la causa determinante o capaz de enervar la sustancia fenomenológica y fáctica, que sigue residiendo en el resultado mismo achacable al Estado, que no sólo está llamado a enfrentar a la delincuencia, a los grupos irregulares, sino que también está obligado, principalmente, a adoptar las medidas de precaución, prevención y contención adecuadas para enfrentar todas las manifestaciones del delito, ya que de lo contrario estaríamos asistiendo a la escenificación de una tragedia colectiva en la que los muertos y los heridos son compatriotas que en cumplimiento de un deber, o en la realización de una misión deben sacrificarse para mantener las instituciones, el sistema democrático, las libertades y el respeto de los derechos en el marco del Estado social, democrático y de derecho.

\section{(...)}

32 Es determinante para la imputación de la responsabilidad que el Estado [sic] el incumplimiento de la planeación, organización, seguimiento y despliegue de la fuerza policial, especialmente en zonas donde el conflicto armado tenía las más complejas, serias y graves circunstancias. Y no debe olvidarse que si se aplica el ius in bellum, el fin último al que debió responder el Estado era 'atenuar, en la medida de lo posible, el sufrimiento causado a las víctimas de las hostilidades', entre las que cabe tener a los policiales que prestando su servicio están cumpliendo con el principio de solidaridad que exige cumplir con ese deber patriótico constitucional. [Negritas del original]. (CE, Sección Tercera, Subsección C, exp. 19195, 31/08/11).

Más allá de la verificación concreta de la responsabilidad en esa especie - se acreditó que los altos mandos de la Policía dejaron a su suerte a un grupo de uniformados en el municipio de Barbacoas, aún ante la evidencia de amenazas reales de un ataque guerrillero, lo que Ilevaría a un análisis en términos de falla del servicio-, lo cierto es que pareciera considerarse que el ejercicio de la profesión de policía o de militar no es una actividad laboral, sino simplemente el ejercicio del deber de solidaridad, lo que no parece compadecerse con el análisis que la misma Corporación ha hecho en torno a los riesgos propios del servicio.

En similares condiciones, la Subsección B de la Sección Tercera, en sentencia de 2013, condenó a la Policía Nacional al pago de los perjuicios derivados de las lesiones sufridas por una enfermera miembro de dicha fuerza pública, con ocasión de un enfrentamiento armado en el que ella fungía como cuerpo asistencial de Ios heridos; en aquella ocasión afirmó:

Cabe en este caso, en consecuencia, acudir a la equidad y la solidaridad para restablecer a la actora en sus derechos a la convivencia pacífica y al orden justo y así mismo exigir de las autoridades la protección de su integridad física y moral. (CE, Sección Tercera, Subsección B, exp. 29081, 6/12/13),

entonces 
al acreditarse suficientemente la ocurrencia de un daño antijurídico, que las personas no tienen el deber jurídico de soportar, lo procedente es ordenar su reparación, en aplicación de los principios de solidaridad y equidad que deben gobernar las relaciones de los ciudadanos en un Estado social de derecho. (CE, Sección Tercera, Subsección C, exp. 28644, 12/06/14).

Las razones que se vienen reseñando constituyen en la actualidad, al menos eso parece, jurisprudencia unificada de la Sección Tercera, pues hacen parte de la reconocida sentencia de unificación en la que se reconoce el carácter aproximativo o relativo de los regímenes de responsabilidad, pudiendo el juez aplicar de manera libre, aunque motivada, el régimen que mejor se ajuste a los hechos del caso. En el asunto del daño especial consideró que en estos casos se

reúne una buena muestra de los eventos en que, con el ánimo de buscar un resultado satisfactorio desde una óptica de justicia material, se utiliza la equidad para reequilibrar las cargas públicas, honrando así el principio de igualdad (...) objetivo que se alcanza gracias a la asunción del principio de solidaridad como argumento de impulsión de la acción reparadora del Estado. (CE, Sección Tercera, exp. 16696, 3/05/07).

Y ello, por cuanto

el padecimiento de ese daño desborda el equilibrio de las cargas públicas y rompe con los principios de solidaridad y equidad (...) Como sea que los hechos que dieron lugar al daño por el cual hoy se reclama ocurrieron en el marco del conflicto armado interno y resulta evidente que es al Estado a quien corresponde la búsqueda de soluciones que conlleven a la terminación de la guerra, de ahí que debe convenirse en que se aparta de los más elementales criterios de justicia y equidad que al producirse estos ataques subversivos, el Estado no acuda a socorrer a sus víctimas. (CE, Sección Tercera, exp. 21515, sentencia de unificación del 19/04/12). ${ }^{30}$

En este último razonamiento se encuentra el quid del asunto. En materia de actos terroristas y aún en ausencia de cualquier imputación concreta, los daños ocurridos con ocasión de Ios actos terroristas resultan imputables al Estado de manera global y genérica -aunque ello requiera en los más de los casos argumentos de concreción en deberes especiales de cuidado o en omisiones específicas de las autoridades-, pues en últimas es al Estado a quien corresponde la búsqueda de soluciones que conlleven a la terminación de la guerra.

Pero, en un caso en el que se cuestionaba la responsabilidad del Estado por los daños sufridos en un inmueble de propiedad del demandante, con ocasión de una toma guerrillera, la misma Sección consideró:

Es la ruptura del equilibrio [sic] las cargas públicas, y la solidaridad como trasfondo filosó-

30. Cf., también, Consejo de Estado, Sección Tercera, exp. 15591, 18/03/10. 
fico que la orienta, el eje de la atribución de responsabilidad en estos casos, pues comprendida dentro del marco del Estado social de derecho, $-\mathrm{y}$ consagrada normativamente en el artículo $1^{\circ}$ constitucional- resulta razonable imponer al Estado, en representación de la sociedad, la obligación de indemnizar a quienes materialmente se han visto afectados con el despliegue de una acción desplegada por grupos armados insurgentes (CE, Sección Tercera, Subsección C, exp. 28618, 14/05/14)

razón por la cual

el tratamiento que se pueda dar al hecho del tercero en la visión propia a los tiempos que corren, no permite que sigamos anclados en el modelo clásico causalista, y nos centremos en la vocación que el instituto de la responsabilidad debe atender: herramienta complementaria para tutela de los derechos de los administrados, especialmente de los derechos humanos; factor de convivencia y del logro de la paz, y; instrumento que permita la aplicación de una justicia redistributiva donde sea el principio de solidaridad el que opere, no la visión individualista propia a los orígenes del mismo instituto. (CE, Sección Tercera, Subsección C, exp. 28618, 14/05/14).

La finalidad de este aparte no era otra que la de poner de presente lo que se podría denominar el argumento de solidaridad en la jurisprudencia de la Corte Constitucional y en la del Consejo de Estado, en otras palabras, su uso, utilización y utilidad tanto en el ámbito general del universo jurídico nacional como en el específico de la responsabilidad del Estado. Corresponde ahora entrar a determinar si el escenario de la responsabilidad es adecuado o propicio para ese argumento de solidaridad, o si bien su función ha sido la de borrar las fronteras de dicha institución con un criterio de justicia distinto del que correspondería a tal análisis.

\section{EN BUSCA DEL FUNDAMENTO DEL DEBER DE REPARAR}

Se ha establecido que la solidaridad ha sido un fundamento válido por parte de la jurisdicción de lo contencioso administrativo para encontrar comprometida la responsabilidad del Estado ya sea desde el punto de vista de la antijuridicidad del daño o bien a partir del análisis de la imputación -por supuesto, la imputación jurídica-. Corresponde, entonces, determinar si la solidaridad puede considerarse un fundamento válido de la declaratoria de la responsabilidad o si ambas instituciones, aunque en ocasiones puedan coincidir en cuanto a sus fines y efectos, son esencial y sustancialmente distintas en su naturaleza.

\section{A. La responsabilidad como fundamento del deber de reparar frente a la solidaridad como fundamento del deber de reparar}

Resulta claro que en la solidaridad puede encontrarse el origen de algunas obligaciones en un Estado social de derecho, es decir, puede 
ser fuente de obligaciones tanto para los particulares como para el Estado. Ello no permite, sin embargo, considerar a la solidaridad como la base teórica, conceptual y normativa del derecho de la responsabilidad extracontractual del Estado, pues el artículo 90 constitucional no se nutre del principio de solidaridad (1); tal acercamiento que ha hecho, como se demostró en acápites anteriores, el Consejo de Estado principalmente en el ámbito del conflicto armado, ha tenido dos consecuencias nefastas: su aplicación a través del daño especial y la inadecuada utilización de la imputación objetiva como basamento argumentativo en los juicios de responsabilidad civil (2).

1. El artículo 90 constitucional no se nutre del principio de solidaridad

En la primera parte de este trabajo quedó en evidencia que desde el punto de vista constitucional, la solidaridad se erige como: i) un valor fundante del Estado, ii) un principio propio del Estado social de derecho, iii) un deber ciudadano, iv) un derecho que puede ser exigido tanto al Estado como a los particulares, cuando un ciudadano se encuentre en condiciones de vulnerabilidad.

Como se indicó, la jurisprudencia de la Corte Constitucional lo asume como un estándar de conducta particular o de política pública, de con- tenido limitado, cuya esencia la constituye el auxilio o la ayuda a personas que se encuentren en condiciones de indefensión ante las circunstancias o riesgos de la vida en comunidad, que explica o justifica determinada concepción del gasto público social y que puede llegar, incluso, a generar, si así lo desea el legislador, la asunción de la obligación de reparar determinados daños.

El instituto de la responsabilidad es distinto. 0 al menos conceptualmente, obedece a fundamentos esencialmente diferentes.

Resulta evidente que, en lo jurídico, el vocablo responsabilidad tiene diferentes acepciones, ${ }^{31}$ sin embargo, sin entrar en ese profundo debate filosófico, es conveniente restringir el concepto de responsabilidad a aquel que se decanta, desde un punto de vista procesal y sustancial, ${ }^{32}$ a partir del artículo 90 constitucional, es decir, aquel que indica que el objeto de la responsabilidad patrimonial del Estado requiere necesariamente de la existencia de un daño y que ese daño sea imputable al Estado -en un sentido amplio-, en cuanto sea "causado por la acción o la omisión de las autoridades públicas". Es decir, se requiere, en cualquier caso, que exista un juicio en el que se determine que el daño sufrido por la parte actora, en tanto que antijurídico -así se ha entendidoes imputable a una entidad pública, siempre y cuando su causa la constituya la conducta activa u omisiva de las autoridades públicas.

31. Ni qué decir de las definiciones que en su uso común puede tener. De manera somera, Gil Botero (2011, pp. 1-6) presenta esta dificultad en su obra.

32. Que difiere del acercamiento más general que de dicho concepto hace el profesor Henao (2015, pp. 31-117). 
En este sentido, la responsabilidad deviene necesariamente de un juicio de imputación, de un juicio de la conducta de la entidad pública demandada, se encuentre o no una falla en el servicio -o trátese o no de funcionamiento anormal de la Administración Pública-; lo cierto es que se debe realizar, necesariamente, un análisis de la incidencia que pudo tener la conducta, activa u omisiva, de la entidad pública demandada en la producción del daño. En paralelo, el principio de solidaridad, como se indicó, resalta un estándar normativo -pero ciertamente anclado en el momento histórico concreto- bajo el cual se debe realizar un análisis de las determinadas circunstancias en que se encuentre un grupo de personas - 0 , excepcionalmente una persona en particularpara definir un curso de acción de las personas públicas o privadas, o al menos una conducta que les es exigible con base en dicho principio, desde un punto de vista de la política pública.

Así, resulta válido considerar que en el ordenamiento jurídico patrio, por la morfología propia del modelo de Estado que se adoptó en la Constitución Política de 1991, la solidaridad puede constituir un fundamento del deber de reparar, al mismo título -pero no lo suplan- ta- que la declaratoria de responsabilidad. Se defiende aquí -aunque no se comparte en su integridad-, entonces, la teoría según la cual podría ser válido afirmar que el principio de solidaridad puede ser fuente de obligaciones, aunque, en todo caso, se debe señalar enérgicamente que la solidaridad no es un sucedáneo de la responsabilidad. ${ }^{33}$

De esta manera, es factible admitir que por razones de política pública o aun por cuestiones propias de las falencias del aparato público colombiano, la solidaridad se erige en una obligación de asumir un daño, no porque se haya causado sino porque el ordenamiento jurídico establece dicho deber. Cuestión diferente se evidencia en aquel caso en que la conducta -activa u omisiva- del Estado causó el daño concreto que sufre la víctima directa, lo que compromete su responsabilidad en virtud del dispositivo contemplado en el artículo 90 de la Constitución Política.

Sin embargo, debe quedar claro que se trata de dos situaciones sustancialmente distintas: ${ }^{34}$ en el primer caso, en el de la solidaridad como fundamento del deber de reparar, se atribuye normativamente la obligación de

33. Por ello, se puede válidamente concluir que "si bien la solidaridad constituye un fundamento complementario de la responsabilidad del Estado en todos los casos, dado que las condenas que a éste se imponen se pagan siempre con dineros del presupuesto público, dicho principio no permite justificar autónomamente tal responsabilidad, puesto que para que ella se configure se requiere que el perjuicio resulte imputable al Estado, por haberlo causado materialmente, obrando ilícita o lícitamente, en éste último caso rompiendo el equilibrio de los ciudadanos frente a las cargas públicas; por haber propiciado o facilitado, con su actuación ilícita, la causación del daño por terceros, o por haber creado conscientemente, en ejercicio de una actuación lícita, el riesgo de que ellos actuaran” (M’Causland, 2013, p. 567).

34. En efecto, "el deber de solidaridad existe, en cabeza del Estado, aún en eventos en los que las situaciones de especial inferioridad en que se encuentran determinadas personas no le son imputables, mientras que la responsabilidad de éste sólo se configura cuando tales situaciones constituyen un daño que le es imputable" (M'Causland, 2013, p. 560). 
reparar un daño, independientemente de las causas o motivos que condujeron a su producción; en el segundo, el de la responsabilidad como fundamento del deber de reparar, se atribuye la causación del daño, lo que genera consecuencialmente dicho deber.

Ahora bien, no se debe excluir la posibilidad de que si existe un mandato de concreto cumplimiento en virtud del principio de solidaridad, radicado personalmente en un particular o en un grupo de particulares, su incumplimiento pueda llegar a comprometer su responsabilidad, pero dicha afirmación difiere profundamente de la consideración según la cual, el principio de solidaridad es fuente de la responsabilidad del Estado. Tampoco quiere decir esto, por otra parte, que cada vez que las autoridades públicas deban responder por los daños causados por un tercero, dicha consideración se justifique en el principio de solidaridad, pues todo dependerá del grado de intervención que la conducta de la autoridad pública tuvo en la producción del daño.

2. La desnaturalización del régimen de la responsabilidad extracontractual del Estado por la inadecuada aplicación

del principio de solidaridad

En este orden de ideas, el fenómeno al cual se asiste presenta dos facetas diferentes pero íntimamente ligadas, según que el énfasis en la determinación del daño antijurídico se ubique en el elemento daño o en el elemento de su antijuridicidad: i) La objetivación del daño antijurídico, por su identificación con el daño especial; ii) La ampliación del concepto daño antijurídico a partir del concepto de imputación jurídica.

i) La objetivación del daño antijurídico por su identificación con el daño especial. Buena parte de los problemas de la dimensión teórica que se le ha intentado dar a la jurisprudencia del Consejo de Estado se debe a la dificultad de conceptualizar adecuadamente el daño antijurídico. Existe un aparente consenso, para no entrar en mayores elucubraciones teóricas acerca de esa definición, en que un daño antijurídico es aquel daño que no se tiene el deber jurídico de soportar. Fórmula tan pegajosa como críptica e imprecisa. Pegajosa por su aparente simplicidad y por lo concreto de su formulación, pero críptica e imprecisa porque son muchos los elementos que se mantienen sin definir. En efecto, qué quiere decir deber jurídico de soportar un daño. En el ordenamiento jurídico nacional, ya se vio, se ha confundido daño con daño antijurídico pero daño antijurídico con daño especial.

Así, por ejemplo, se ha considerado que el daño antijurídico es el primer elemento de la responsabilidad, ${ }^{35}$ pero también se ha dicho

35. Así, por ejemplo, el Consejo de Estado ha dicho: "Para que un daño sea antijurídico y, por ende, indemnizable, es indispensable verificar ex ante la configuración de los elementos que lo estructuran, es decir, que sea cierto, actual, real, determinado o determinable y protegido jurídicamente. En síntesis, estos elementos parten de la premisa según la cual, la antijuridicidad del daño no se concreta solo con la verificación de la lesión de un derecho o de un interés legítimo, sino con los efectos derivados 
que daño antijurídico es aquel que no se tiene el deber jurídico de soportar porque vulnera el equilibrio de las cargas públicas. El asunto se complica aún más, si se tiene en cuenta que para los artífices de la figura, García de Enterría y Fernández (2008), la antijuridicidad del daño es un elemento propio de la imputación o, si se quiere, del nexo de causalidad. En efecto, para dichos autores:

El concepto técnico de lesión resarcible, a efectos de responsabilidad, requiere, pues, un perjuicio patrimonialmente evaluable, ausencia de causas de justificación, no en su comisión, sino en su producción respecto al titular del patrimonio contemplado y, finalmente, posibilidad de imputación del mismo a tercera persona (en este caso la administración), puesto que si el perjuicio se imputase al mismo titular no habría antijuridicidad, porque nadie puede hacerse agravio a sí mismo, ni cabe imaginar tampoco un autodeber de reparación, y si se imputase a una causa extraña o a fuerza mayor, sobre faltar también la nota de antijuridicidad, no existiría un sujeto al que atribuir el deber de resarcimiento, que es la finalidad última de la institución. (2008, p. 367).

Así, en presencia de causales eximentes de responsabilidad que afectan el nexo causal o el juicio de imputación, según la corriente teórica que se siga, para los autores en cita se rompería el carácter antijurídico del daño. Es decir, se trata de un criterio de imputación de resultados dañosos -fáctica o jurídicamente-. De allí que, en muchas ocasiones, en el sistema colombiano se tienda a determinar si la víctima tenía el deber jurídico de soportar el daño, en el juicio de imputación y no en esa supuesta primera etapa. Ello se puede deber a la ausencia de una referencia expresa a la causación del daño por parte del Estado en el derecho español, lo que hace que el análisis de la antijuridicidad sea omnicomprensivo de la responsabilidad del Estado puesto que incluye el análisis de la imputación.

En todo caso, no existe duda en cuanto a que el artículo 90 constitucional modificó la perspectiva de análisis, puesto que se pasó de poner el énfasis en la conducta de la entidad pública a centrar el análisis en sus efectos. Ya es un lugar común lo que el Consejo de Estado ha afirmado al respecto:

La antijuridicidad del perjuicio no depende de la licitud o ilicitud de la conducta desplegada por la Administración sino de la no soportabilidad del daño por parte de la víctima. De otro lado, la concepción del daño antijurídico a partir de la consideración de que quien lo sufre no está obligado a soportarlo constituye otra forma de plantear el principio constitucional según el cual, la igualdad frente a las cargas públicas es sustento de la actividad de la ad-

de la lesión que inciden en el ámbito patrimonial o extrapatrimonial, los cuales son injustamente padecidos por la víctima" (Sección Tercera, Subsección B, exp. 31190, 29/08/14); en idéntica dirección, cf. Consejo de Estado, Sección Tercera, Subsección C, exp. 30385, 1/07/15. 
ministración pública. (CConst., C-254/2003, M. Monroy). ${ }^{36}$

En idéntica dirección, esa Corporación, en una sentencia en la que buscaba determinar la responsabilidad que le podía incumbir al Ejército Nacional por los perjuicios sufridos por un conscripto - sujeto que presta el servicio militar obligatorio-, afirmó:

Tratándose de una situación como la mencionada, considera la Sala que el daño será antijurídico cuando en virtud de él resulte roto el equilibrio frente a las cargas públicas, es decir, cuando, dada su anormalidad, implique la imposición de una carga especial e injusta al conscripto o a sus familiares en relación con las demás personas. (CE, Sección Tercera, exp. 11401, 2/03/2000).

Así mismo, en sentencia del 5 de diciembre de 2005, la Sección Tercera del Consejo de Estado aseguró:

La primera: no todos los daños que causa el Estado resultan indemnizables, sobre todo si los mismos son el resultado de la actividad estatal lícita, pues solamente originan el deber de reparación patrimonial aquellos daños que exceden los límites jurídicos que garantizan los derechos e imponen obligaciones exigibles a todas las personas que viven en determinada sociedad. Se ve, entonces, cómo la concepción del daño antijurídico, desde esa perspectiva, no solamente resulta acorde con los principios de eficiencia de la función pública y efectividad de los derechos (artículos 228 y $2^{\circ}$ de la Constitución), sino también confluye con los principios de igualdad frente a las cargas públicas y solidaridad, que constituyen las piezas angulares del Estado Social de Derecho (artículos $1^{\circ} \mathrm{y}$ 13 de la Carta). (Exp. 12.158, 5/12/05).

Nótese cómo el Consejo de Estado confunde la antijuridicidad del daño con daño especial, en la medida en que pretende sustentar la primera institución en el equilibrio de las cargas públicas, ${ }^{37}$ cuando se tiene por sentado que ese no es el fundamento de la falla del servicio o del riesgo excepcional. Lo cierto, sin embargo, es que esa confusión se deriva del hecho de que la categoría daño especial se ha convertido en un comodín para atribuir el deber de reparar en aquellos casos en que, partiendo de una situación que el juez estima injusta o

36. Así mismo, "el artículo 90 de la Carta, atendiendo las construcciones jurisprudenciales, le dio un nuevo enfoque normativo a la responsabilidad patrimonial del Estado desplazando su fundamento desde la falla del servicio hasta el daño antijurídico. Ello implica la ampliación del espacio en el que puede declararse la responsabilidad patrimonial del Estado pues el punto de partida para la determinación de esa responsabilidad ya no está determinado por la irregular actuación estatal -bien sea por la no prestación del servicio, por la prestación irregular o por la prestación tardía- sino por la producción de un daño antijurídico que la víctima no está en el deber de soportar, independientemente de la regularidad o irregularidad de esa actuación. (CConst., C-285/2002, J. Córdoba).

37. En ocasiones, también, es el deber de reparar el que se encuentra ligado al equilibrio de las cargas públicas, por ejemplo cuando se afirmó que "verificada la ocurrencia de un daño, surge el deber de indemnizarlo plenamente, con el fin de hacer efectivo el principio de igualdad ante las cargas públicas, resarcimiento que debe ser proporcional al daño sufrido” (CE, Sección Tercera, Subsección C, exp. 31056, 28/01/15). 
inicua, decide atribuir la carga de repararlo a la Administración, es decir, en diversas ocasiones el ejercicio intelectual del juez se resume a insertar dentro de un argumento circular -el daño antijurídico es el que no se tiene el deber de soportar, y no se tiene el deber de soportar lo que es antijurídico- sus propias consideraciones jurídicas, ideológicas o políticas para determinar que es la Administración Pública la que debe asumir la reparación de determinado perjuicio.

En línea con estas reflexiones, solo se puede concluir, siguiendo a M'Causland (2013), a manera de crítica a la objetivación del daño antijurídico por su aproximación al daño especial, que "en estos casos [ataques terroristas] la sola antijuridicidad del daño no bastará para que nazca la obligación del Estado de indemnizar los perjuicios que de él se deriven, puesto que no estará establecido que aquél es imputable al Estado" (p. 551).

ii) Por otra parte, el uso indebido de la imputación objetiva para darle aplicación al criterio de imputación jurídica también ha generado una verdadera tendencia hacia la hipertrofia de la responsabilidad extracontractual del Estado en el derecho colombiano. No resulta pertinente entrar a analizar en detalle la figura de la imputación objetiva, pero de manera general se puede afirmar que esta institución, de origen civilista, entró al ámbito de la responsabilidad del Estado por la influencia que en algún momento tuvo alguna vertiente de la teoría funcionalista alemana en el derecho español y en el derecho nacional, puesto que se consideró que podría constituir una herramienta útil para la atribución de responsabilidad por hechos realizados por terceros, en los que no interviniera de manera directa la conducta de las autoridades públicas y, principalmente, para casos en que se pretendía imputar una omisión del Estado. ${ }^{38}$

Los reparos a esta postura no son del todo desconocidos. En primer lugar, resulta difícilmente aceptable que se traiga, sin modificaciones como aquí se ha hecho, una institución propia de un sistema de responsabilidad tan particular como es el penal, en el que se analiza la culpa personal del agente causante de un ilícito, a la luz de principios como el de la presunción de inocencia, a un ámbito de responsabilidad anónima del servicio, cuya única finalidad ha sido la de atribuir resultados, pero no intervenciones de las entidades públicas en el curso causal. En segundo lugar, si se analiza con detenimiento y se adecúa al ámbito de la responsabilidad del Estado, la imputación objetiva -en el caso nacional se ha manejado a partir de relaciones de especial sujeción y de posición de garantía- debe conducir necesariamente a la atribución de un deber concreto de conducta en determinadas situaciones, de allí que la ocurrencia del hecho dañoso implique el incumplimiento de un deber a cargo del Estado que compromete su responsabilidad;

38. Para un análisis completo de esta teoría, ver Molina (2013), en particular el capítulo 3. 
en este sentido la imputación objetiva sería un criterio válido para determinar la existencia de una falla del servicio y no, como se ha entendido, de aplicación de un régimen objetivo de responsabilidad.

La cuestión es que los dos fenómenos a los que se ha hecho referencia, por las falencias conceptuales que se han reseñado y el indebido manejo jurisprudencial del que han sido objeto ambas instituciones -daño especial e imputación objetiva - han contribuido no solo a expandir los supuestos de hecho de la responsabilidad del Estado, sino a prescindir de todo juicio de causalidad atribuible al Estado.

En este sentido, la atribución de la responsabilidad del Estado se desarrolla en un ámbito estrictamente argumentativo a partir de la interpretación de las normas que de una u otra manera, concretamente o no, le hayan atribuido algún deber genérico de protección. En este análisis normativo el juez echa mano de todo el ordenamiento para determinar si, desde el punto de vista jurídico, independientemente del agente productor del daño, el Estado debe resarcir el perjuicio sufrido por la víctima.

Lo anterior se evidencia sin mayor problema en la ampliación constante que se ha generado en materia de actos terroristas, en los que se pasó de la tradicional -y muy útil- falla relativa del servicio a la atribución de responsabilidad con la sola verificación de un contexto de violencia en el que se produzcan determinados daños (CE, Sección Tercera, Subsección B, exp. 26958, 28/05/15) o, en casos muy particulares, con la sola verificación del daño, sin que se requiera acreditar nada más que el escenario en el cual se produjo. ${ }^{39}$ Sucede así, también, en el caso de las infecciones intrahospitalarias, en las que normativamente se consideró que el riesgo se atribuía al Estado, con la exclusiva verificación de su ocurrencia, aun en condiciones normales de ejecución del servicio (CE, Sección Tercera, Subsección A, exp. 21661, 27/06/12). En estos casos, la única conclusión posible es que el juez, en cuanto artífice de una determinada política jurisprudencial, atribuya la responsabilidad por razones de solidaridad o por un particular entendimiento de la equidad, pero que no realice un juicio de atribución de responsabilidad en estricto sentido.

Si se asume esa distinción se deben encontrar unas consecuencias limitativas de la responsabilidad del Estado o, al menos, un cambio de perspectiva, como se verá a continuación.

\section{B. Diferencias profundas entre uno y otro sistema}

Se probó que en el caso de la solidaridad como fundamento del deber de reparar, se atribuye a las autoridades públicas el deber de soportar la reparación de un daño, aun cuando su

39. Como ocurre en el caso de los enfrentamientos entre las fuerzas del orden y los grupos armados al margen de la ley. 
conducta no haya contribuido a su causación; mientras que en el caso de la responsabilidad, el deber de reparar deviene de la intervención decisiva del agente causante en la producción del daño alegado. En el primer caso se imputan las causas del daño, en el segundo se atribuye exclusivamente el deber de repararlo.

Ello conlleva numerosas consecuencias en cuanto a las diferencias entre uno y otro fundamento del deber de reparar que atañen a su sustrato normativo, al alcance de la responsabilidad, el alcance de la reparación y a los poderes del juez para declararlos.

\section{En cuanto al fundamento normativo}

Por supuesto que si el fundamento del deber de reparar difiere en cuanto a la intervención decisiva en la causación del daño del agente a quien se pretende imputar la reparación del daño, resulta evidente que existen distintos fundamentos normativos frente a uno y otro caso.

En el ámbito de la responsabilidad, existe consenso en que el fundamento del deber de reparar se desprende del artículo 90 de la Constitución Política, en la medida en que hace directa referencia a la causación del daño como elemento esencial en un juicio de responsabilidad. Ello no excluye la posibilidad de que en cada juicio concreto de responsabilidad se pueda evidenciar, por un lado, la violación de un contenido obligacional directamente determinado en alguna disposición de estirpe constitucional, como por ejemplo, aquellas que se encuentran genéricamente en el artículo 2 del texto constitucional, en el 58 ejusdem en tratándose de limitaciones a la propiedad privada o directamente en aquellos casos en que se constituyan monopolios (art. 336 C. P.) o se opere la publicatio de servicios públicos que se ejecutaban en condiciones de libre mercado o que los contenidos obligacionales se encuentren determinados en disposiciones normativas de rango legal o reglamentario.

Lo anterior tampoco excluye que según el régimen de responsabilidad escogido, el fundamento normativo de la responsabilidad se encuentre en la violación de un deber funcional contenido en el sistema normativo de referencia de la actividad desplegada, o en la concreción de un riesgo creado o aprovechado por la Administración Pública o bien, como ocurre con el daño especial, en el artículo 13 de la Constitución Política.

La solidaridad, por su parte, encuentra un postulado general en el artículo primero de la Constitución Política, por cuya virtud,

Colombia es un Estado social de derecho, organizado en forma de República unitaria, descentralizada, con autonomía de sus entidades territoriales, democrática, participativa y pluralista, fundada en el respeto de la dignidad humana, en el trabajo y la solidaridad de las personas que la integran y en la prevalencia del interés general. [Cursivas añadidas].

Reiterado en el artículo 95, num. 2 del texto fundamental, al establecer los deberes de los co- 
lombianos, mediante la indicación de que todo colombiano deberá “obrar conforme al principio de solidaridad social, respondiendo con acciones humanitarias ante situaciones que pongan en peligro la vida o la salud de las personas".

De esta manera, resulta distinto, al menos desde el punto de vista normativo, acudir a la solidaridad como fundamento del deber de reparar, de aquel que se basa en la existencia de la responsabilidad del Estado.

Dicha apreciación invita también a desligar el daño especial de toda consideración relativa a la solidaridad, en la medida en que en ese evento no se trata de socorrer a un tercero de las circunstancias concretas en las que se encuentra, sino de resarcir un daño causado por una actividad legítima del Estado que, por su carácter excepcional y anormal, debe considerarse como una vulneración del principio/derecho de igualdad.

2. En cuanto al alcance de los poderes del juez

Si se trata de fundamentos distintos, y si el artículo 90 constitucional no se encuentra en la base de la aplicación del principio de solidaridad para justificar el resarcimiento de los perjuicios derivados de conductas que no se puedan imputar concretamente al Estado -bajo un juicio concreto de valoración fáctica o normativa de la intervención de la conducta de la Administración en la producción del daño-, se requiere un cambio en las potestades del juez.
Lo primero, respecto de lo cual se debe enfatizar con mucho vigor, es que de no encontrarse aplicable el artículo 90 constitucional, el juez de la acción de reparación directa debe perder competencia para pronunciarse sobre la compensación de los daños; es decir, un juicio de responsabilidad patrimonial del Estado no puede tener sustento en norma constitucional distinta de aquella que la establece expresamente, puesto que las acciones contencioso administrativas -las subjetivas- solo pueden buscar la declaratoria de responsabilidad como fundamento concreto de su consecuencia, es decir, de la obligación de reparar el daño causado.

Ahora bien, si se quiere continuar en la vía de la controversia contenciosa aun cuando no se evidencia un criterio de imputación concreto -ya se probó que los criterios utilizados en la actualidad para definir la imputación jurídica no son adecuados, por decir lo menos-, se requiere abandonar dos ideas que han defendido ferozmente aun quienes propugnan por la ampliación del criterio de imputación: el carácter declarativo de la pretensión de responsabilidad del Estado, por una parte, y el carácter indemnizatorio de la acción de reparación directa -en la cual no se cree, pero que ha sido defendida por una parte de quienes asumen la solidaridad como fundamento válido de la responsabilidad-.

En cuanto a la primera de esas cuestiones, no queda duda de que ante la ausencia del criterio de imputación concreto, es decir, al romper de manera directa la posibilidad de considerar que el daño alegado efectivamente fue cau- 
sado por la conducta activa u omisiva de las autoridades públicas, pero que a pesar de ello existe el deber de reparar fundamentado en una interpretación del principio de solidaridad, se requiere prescindir de la pretensión declaratoria pues no habría lugar a su aplicación, sino simplemente decretar la indemnización que le correspondería al demandante. Ello, en buena medida, porque el juez no podría argumentar válidamente, bajo ningún régimen consolidado o no, la responsabilidad como fundamento del deber de reparar ante la ausencia de uno de sus elementos, sino que, por razones de justicia distributiva, el juez considera que el demandante merece una compensación por la especial situación de angustia, peligro o miseria en la que este se encuentra.

El asunto de los perjuicios y el carácter de la acción de reparación directa serán tratados en el punto siguiente.

\section{En cuanto al alcance de la reparación}

La cuestión de los perjuicios tiene necesariamente que ver con el fundamento del deber de reparar; no de otra manera puede entenderse, entonces, lo que el mismo Consejo de Estado, en una sentencia de acción de grupo de 2007 en la que se cuestionaba la responsabilidad del Estado con ocasión del desplazamiento forzado sufrido por unas personas en la zona del Catatumbo a causa de grupos paramilitares-, afirmó:
De la indemnización que reciban los beneficiarios de esta condena no se descontará el valor de los bienes que hubieren recibido por parte del Estado durante el desplazamiento porque tales bienes les son entregados a las víctimas de tales delitos no a título de indemnización sino en desarrollo del principio de solidaridad, como ayuda humanitaria para su subsistencia en el momento en que se produzca el hecho o durante el tiempo posterior, para su retorno o asentamiento a través de la implementación de proyectos económicos, en tanto que la indemnización que aquí se reconoce tiene como causa la responsabilidad patrimonial de la entidad demandada por la causación de un daño antijurídico que le es imputable, de conformidad con lo previsto en el artículo 90 de la Constitución. (CE, Sección Tercera, exp. AG-004, 15/08/07).

A igual conclusión se debe arribar si se considera que, en reciente sentencia, el Consejo de Estado condenó al Estado al pago de lucro cesante - consolidado y futuro- a favor del hijo de una soldado profesional muerta en combate, como consecuencia de una falla en el servicio de los mandos superiores, pero además ordenó, a título de medidas de reparación no pecuniarias, que fuera "reconocido como víctima del conflicto armado, razón por la que se solicita a las instancias gubernamentales competentes incorporarlo y surtir los procedimientos consagrados en la ley 1448 de 2011" (CE, Sección Tercera, Subsección C, exp. 30385, 1/07/15). ${ }^{40}$

40. En esta misma sentencia, la Subsección - para los efectos, compuesta por dos magistrados-, ordenó que se incluyeran en las negociaciones de paz lo relativo a los daños ambientales producidos por los ataques a la infraestructura. 
Ello se encontraría, en principio, en consonancia con lo establecido por el propio ordenamiento jurídico relativo a las víctimas del conflicto armado, en la medida en que, al menos desde el Decreto 444 de 1993, se reconoció normativamente que la ayuda humanitaria entregada no excluye la posibilidad de que el Estado sea condenado por las actividades que motivaren su otorgamiento. ${ }^{41}$

En la medida en que el ordenamiento contencioso administrativo nacional ha identificado el origen del daño con el medio de control procedente, una condena basada solamente en el principio de solidaridad -no en su vulneración- sino como fundamento del deber de reparar, no debería tener lugar, puesto que ello vulneraría el principio de congruencia, máxime cuando no se ha contemplado expresamente como un aspecto propio del cauce procesal aludido. Pero, de considerarse que por razones de justicia distributiva una tal condena podría proceder, lo cierto es que no tendrían aplicación ni podrían aplicarse los criterios propios de la reparación integral, en la medida en que al no ser atribuible la causación del daño a la entidad pública, sino solamente su reparación, el sistema debe tener en cuenta que lo que se busca es auxiliar a la persona que se encuentra en situación de peligro, miseria o angustia, pudiendo establecer cualquier medida adecuada que satisfaga ese ideal de justicia distributiva para compensar dicha situación.
Pero no podría alegarse válidamente, a menos que la ley lo establezca concretamente, que el Estado deberá resarcir integralmente los perjuicios que no ha causado. Al respecto se debe recordar que solo se debe reparar el daño, todo el daño y nada más que el daño, y solo se está obligado a hacerlo en la medida en que se haya causado.

De allí que los cauces adecuados para asumir las consecuencias patrimoniales de un daño con base en el principio de solidaridad, correspondan a mecanismos de política pública, legislativos, en los que se sopesa de manera global -macroeconómica- el impacto de dichas medidas en el gasto público social y, bajo la égida de la libertad de configuración del legislador, en un marco de progresividad, se escogen los asuntos, temas o circunstancias que requieran una atención más urgente por parte de las autoridades públicas, como ocurre frente a las víctimas del conflicto armado, los damnificados por calamidades públicas, etc.; mientras que, por otra parte, las sentencias proferidas en el curso de procesos de reparación directa sirven pobremente a esos fines de progresividad, porque su principal finalidad es la de resolver un litigio y acordar una indemnización a quien haya sufrido un perjuicio.

Bajo esa lógica, se ha considerado -aunque no se esté de acuerdo con ello- que el medio de control de reparación directa tiene un

41. En los términos del artículo 29 del referido Decreto, “la asistencia que la Nación o las entidades públicas presten a las víctimas de los atentados terroristas, en desarrollo de lo dispuesto en el presente Decreto y de los programas de atención que al efecto se establezcan, no implica reconocimiento por parte de la nación o de la respectiva entidad de responsabilidad alguna por los perjuicios causados por el atentado terrorista" (CE, Sección Tercera, exp. 14211, 23/10/03). 
carácter reparatorio, no compensatorio. En el caso de la solidaridad, nada se repara, todo se compensa. En el caso de los daños antijurídicos irrogados en el patrimonio de una persona como consecuencia de la conducta activa u omisiva de las autoridades públicas, todo se repara, poco se compensa.

En todo caso, los sistemas de reparación administrativa fundamentados en el principio de solidaridad deben entenderse como pagos -totales o parciales-, por lo que deberían descontarse de la indemnización debida, tal y como lo disponen $-y$ lo han dispuesto- ${ }^{42}$ las diferentes disposiciones normativas que han regulado la materia, a las cuales no podrá, bajo ningún concepto sustraerse el juez. En efecto, tal y como lo dispone el artículo 20 de la Ley 1448 de 2011, "la indemnización recibida por vía administrativa se descontará a la reparación que se defina por vía judicial. Nadie podrá recibir doble reparación por el mismo concepto", disposición normativa que debe ser interpretada en consonancia con lo normado en los artículos $25^{43}$ y 133 , en cuanto a concurrencia de reparaciones en tratándose de ayuda humanitaria y reparación administrativa o judicial.

\section{A MANERA DE CONCLUSIÓN. UNA CUESTIÓN DE PRINCIPIO: LA HIPERTROFIA DE LA RESPONSABILIDAD DEL ESTADO FUNDAMENTADA EN LA SOLIDARIDAD}

De las reflexiones que anteceden no queda mucho que concluir.

Por una parte, parece resultar claro que la función del principio de solidaridad en el ordenamiento jurídico colombiano no es la de soportar la institución de la responsabilidad; la solidaridad tiene diversas facetas, todas ligadas al deber de auxiliar a las personas que se encuentren en determinadas situaciones por

42. Para un ejemplo, véase el artículo 30 del Decreto 444 de 1993: "ARTíCULO 30. En el evento de que la nación o las entidades públicas sean condenadas a reparar los daños a las víctimas de atentados terroristas, del monto total de los perjuicios que se liquiden se deducirán las sumas que la Nación o las entidades públicas hayan entregado a las víctimas o en favor de las mismas, en razón de lo dispuesto en el presente Decreto y de los programas de asistencia que se adopten, por concepto de:

a). Asistencia humanitaria, médica, quirúrgica y hospitalaria;

b). Gastos funerarios;

c). Seguros;

d). Subsidio de vivienda;

d). Subsidios en materia crediticia;

e). Asistencia en materia educativa, y

f). Otros apoyos suministrados a través de entidades sin ánimo de lucro, con los propósitos a que hacen referencia los artículos anteriores.

PARÁGRAFO. Para efectos de lo dispuesto en el presente artículo, el Fondo de Solidaridad y Emergencia Social llevará una contabilidad detallada de todos los pagos que se realicen.

43. Principalmente lo dispuesto en el parágrafo segundo de dicha norma, según el cual "la ayuda humanitaria definida en los términos de la presente ley no constituye reparación y en consecuencia tampoco será descontada de la indemnización administrativa o judicial a que tienen derecho las víctimas". 
las circunstancias propias de la vida en sociedad; sin embargo, la responsabilidad del Estado no es una de las expresiones del principio de solidaridad.

No obstante lo anterior, la jurisprudencia del Consejo de Estado lo ha utilizado tanto como elemento determinante de la antijuridicidad del daño como elemento del juicio de imputación. De manera velada, entonces, el principio de solidaridad se ha integrado en la jurisprudencia con la finalidad de atribuir responsabilidad en casos en los que no existe curso causal alguno que permita imputar el daño a la autoridad pública, excepto por la vía de una abstracta imputación normativa de la ocurrencia de un resultado concreto, principal pero no exclusivamente, en casos en que se involucran actividades terroristas causadas por terceros. En este sentido, el juicio de responsabilidad del Estado colombiano se resume a un aspecto argumentativo de interpretación de la ley, lo que no parece adecuado.

Ahora, nada obsta para que se considere que tanto la responsabilidad del Estado como el principio de solidaridad puedan constituir fundamentos autónomos del deber de reparar, pero no se puede perder de vista que existen diferencias fundamentales en uno y otro caso.

Mientras que en el juicio de responsabilidad, como fundamento del deber de reparar, se atribuye la causación de un daño por una conducta activa u omisiva del agente a quien le pretendo exigir su reparación, en la determinación del deber de reparar fundamentado en la con- creción normativa del principio de solidaridad se le atribuye necesariamente la reparación de un daño, no su causación. De allí que ninguna responsabilidad o declaratoria de responsabilidad pueda realizarse a ese efecto.

El juicio de responsabilidad conlleva la atribución de los efectos nocivos del hecho dañoso desde una óptica de reparación integral; por su parte, en el juicio de solidaridad, solo se debe determinar el alcance del resarcimiento debido, bajo un criterio de progresividad del gasto público. El criterio de solidaridad solo puede compensar -en la medida de lo posible-, el criterio de responsabilidad, repara, esencialmente, aunque también puede compensar según el régimen de responsabilidad acogido y la naturaleza del perjuicio.

Sin embargo, se debe ser enfático en señalar que el escenario procesal de la responsabilidad del Estado no es el lugar adecuado para poner en marcha el principio de solidaridad. En primer lugar, porque el juez de la reparación directa no tiene competencia para hacer juicios de política pública en este tipo de fallos, como no sean con el fin de atribuir responsabilidad en el caso concreto; en segundo lugar, los principios de justicia rogada y de congruencia impiden un análisis en ese sentido; en tercer lugar, declarar la responsabilidad fundado en un criterio de solidaridad en el contexto del medio de control de reparación directa genera terribles desigualdades entre quienes acudieron a la jurisdicción y quienes no lo hicieron, puesto que se les están generando beneficios a personas concretas bajo una lógica individualista, en 
asuntos en los que se debería tener en cuenta el principio de igualdad en el acceso al gasto público social. Existe, finalmente, un argumento de difícil sustento en términos de igualdad, pues se le atribuye solo a una entidad pública en concreto - la demandada- las falencias propias, generales, crónicas y endémicas del Estado social de derecho colombiano.

Esa tendencia objetivizante, no de la responsabilidad del Estado -lo que puede ser discutible, pero no peligroso- sino de la antijuridicidad del daño, resulta injustificada si se tiene en cuenta que, como una petición de principio, se sigue repitiendo en la jurisprudencia que el Estado no es un garante universal, que no se puede poner un policía detrás de cada ciudadano, pero se le condena por eventos en los que, aparte de una pretendida atribución normativa genérica y abstracta, no se evidencia participación alguna del Estado.

Parece ser el momento de la sinceridad. Que se afirme sin ambages que el Estado colombiano asume la responsabilidad de TODOS los perjuicios derivados del conflicto armado; que por vía de la responsabilidad extracontractual se van a suplir todos los defectos del modelo de Estado que sufrimos y, aún de nuestra sociedad; o bien, lo que parece ser la vía más adecuada, se advierta que la superación de esas dificultades requiere de un esfuerzo global del Estado - con directa y activa participación de la rama judicial, en calidad de legítimo actor político- en el que el juez de la responsabilidad es garante de las obligaciones que asumen las autoridades públicas en el marco constitucio- nal, pero no necesariamente, mediante la jurisprudencia que produce, su actor principal ni mucho menos su artífice.

\section{Referencias}

1. Carrillo Ballesteros, J. (2001). A dos lustros de la vigencia del artículo 90 de la Constitución Política. Revista de Derecho Privado, (7).

2. Coleman, J. (2010). Riesgos y daños. Madrid: Marcial Pons.

3. Consejo de Estado. Sala Plena de lo Contencioso Administrativo. (C. P.: Gustavo A. Valbuena; julio 29 de 1947).

4. Consejo de Estado. Sala de lo Contencioso Administrativo. Sección Tercera. Exp. 6784 (C. P.: Julio César Uribe Acosta; noviembre 22 de 1991).

5. Consejo de Estado. Sala de lo Contencioso Administrativo. Sección Tercera. Exp. 7217 (C. P.: Julio César Uribe Acosta; julio 30 de 1992).

6. Consejo de Estado. Sala de lo Contencioso Administrativo. Sección Tercera. Exp. 7130 (C. P.: Julio César Uribe Acosta; noviembre 26 de 1992).

7. Consejo de Estado. Sala de lo Contencioso Administrativo. Sección Tercera. Exp. 8577 (C. P.: Julio César Uribe Acosta; septiembre 23 de 1994). 
8. Consejo de Estado. Sala de lo Contencioso Administrativo. Sección Tercera. Exp. 11401 (C. P.: Alier Eduardo Hernández Enríquez; marzo 2 de 2000).

9. Consejo de Estado. Sala de lo Contencioso Administrativo. Sección Tercera. Exp. 14211 (C. P.: Ramiro Saavedra Becerra; octubre 23 de 2003).

10. Consejo de Estado. Sala de lo Contencioso Administrativo. Sección Tercera. Exp. 12158 (C. P.: Alier Eduardo Hernández Enríquez; diciembre 5 de 2005).

11. Consejo de Estado. Sala de lo Contencioso Administrativo. Sección Tercera. Exp. 16696 (C. P.: Enrique Gil Botero; mayo 3 de 2007).

12. Consejo de Estado. Sala de lo Contencioso Administrativo. Sección Tercera. Exp. AG-004 (C. P.: Ruth Stella Correa Palacio; agosto 15 de 2007).

13. Consejo de Estado. Sala de lo Contencioso Administrativo. Sección Tercera. Exp. 15591 (C. P.: Enrique Gil Botero; marzo 18 de 2010).

14. Consejo de Estado. Sala de lo Contencioso Administrativo. Sección Tercera. Subsección C. Exp. 20835 (C. P.: Enrique Gil Botero; julio 7 de 2011).

15. Consejo de Estado. Sala de lo Contencioso Administrativo. Sección Tercera. Subsec- ción C. Exp. 19195 (C. P.: Jaime Orlando Santofimio Gamboa; agosto 31 de 2011).

16. Consejo de Estado. Sala de lo Contencioso Administrativo. Sección Tercera. Exp. 21515 (C. P.: Hernán Andrade Rincón; abril 19 de 2012).

17. Consejo de Estado. Sala de lo Contencioso Administrativo. Sección Tercera. Subsección A. Exp. 21661 (C. P.: Mauricio Fajardo Gómez; junio 27 de 2012).

18. Consejo de Estado. Sala de lo Contencioso Administrativo. Sección Tercera. Subsección B. Exp. 29081 (C. P.: Stella Conto Díaz del Castillo; diciembre 6 de 2013).

19. Consejo de Estado. Sala de lo Contencioso Administrativo. Sección Tercera. Subsección C. Exp. 28618 (C. P.: Jaime Orlando Santofimio Gamboa; mayo 14 de 2014).

20. Consejo de Estado. Sala de lo Contencioso Administrativo. Sección Tercera, Subsección C. Exp. 28644 (C. P.: Olga Mélida Valle de de la Hoz; junio 12 de 2014).

21. Consejo de Estado. Sala de lo Contencioso Administrativo. Sección Tercera. Subsección B. Exp. 31190 (C. P.: Ramiro de Jesús Pazos Guerrero; agosto 29 de 2014).

22. Consejo de Estado. Sala de lo Contencioso Administrativo. Sección Tercera. Subsección C. Exp. 31056 (C. P.: Olga Mélida Valle de de la Hoz; enero 28 de 2015). 
23. Consejo de Estado. Sala de lo Contencioso Administrativo. Sección Tercera. Subsección A. Exp. 29338 (C. P.: Hernán Andrade Rincón; febrero 26 de 2015).

24. Consejo de Estado. Sala de lo Contencioso Administrativo. Sección Tercera. Subsección B. Exp. 26958 (C. P.: Stella Conto Díaz del Castillo; mayo 28 de 2015).

25. Consejo de Estado. Sala de lo Contencioso Administrativo. Sección Tercera. Subsección C. Exp. 30385 (C. P.: Jaime Orlando Santofimio Gamboa; julio 1 de 2015).

26. Corte Constitucional de Colombia. Sentencia C-040/1993 (M. P.: Ciro Angarita Barón; febrero 11 de 1993).

27. Corte Constitucional de Colombia. Sentencia C-197/1993 (M. P.: Antonio Barrera Carbonell; mayo 20 de 1993).

28. Corte Constitucional de Colombia. Sentencia T-550/1994 (M. P.: José Gregorio Hernández Galindo; diciembre 2 de 1994).

29. Corte Constitucional de Colombia. Sentencia C-333/1996 (M. P.: Alejandro Martínez Caballero; agosto 1 de 1996).

30. Corte Constitucional de Colombia. Sentencia T-227/1997 (M. P.: Alejandro Martínez Caballero; mayo 5 de 1997).

31. Corte Constitucional de Colombia. Sentencia C-017/1998 (M. P.: Carlos Gaviria Díaz; febrero 4 de 1998).
32. Corte Constitucional de Colombia. Sentencia C-678/1998 (M. P.: Alfredo Beltrán Sierra; noviembre 18 de 1998).

33. Corte Constitucional de Colombia. Sentencia T-389/99 (M. P.: Carlos Gaviria Díaz; mayo 27 de 1999).

34. Corte Constitucional de Colombia. Sentencia SU-1150/2000 (M. P.: Eduardo Cifuentes Muñoz; agosto 30 de 2000).

35. Corte Constitucional de Colombia. Sentencia C-832/2001 (M. P.: Rodrigo Escobar Gil; agosto 8 de 2001).

36. Corte Constitucional de Colombia. Sentencia C-1064/2001 (M. P.: Manuel José Cepeda Espinosa; octubre 10 de 2001).

37. Corte Constitucional de Colombia. Sentencia C-086/2002 (M. P.: Clara Inés Vargas Hernández; febrero 13 de 2002).

38. Corte Constitucional de Colombia. Sentencia C-232/2002 (M. P.: Clara Inés Vargas Hernández; abril 4 de 2002).

39. Corte Constitucional de Colombia. Sentencia C-285/2002 (M. P.: Jaime Córdoba Triviño; abril 23 de 2002).

40. Corte Constitucional de Colombia. Sentencia T-434/2002 (M. P.: Rodrigo Escobar Gil; mayo 30 de 2002).

41. Corte Constitucional de Colombia. Sentencia C-150/2003 (M. P.: Manuel José Cepeda Espinosa; febrero 25 de 2003). 
42. Corte Constitucional de Colombia. Sentencia C-254/2003 (M. P.: Marco Gerardo Monroy Cabra; marzo 25 de 2003).

43. Corte Constitucional de Colombia. Sentencia T-520/2003 (M. P.: Rodrigo Escobar Gil; junio 26 de 2003).

44. Corte Constitucional de Colombia. Sentencia T-419/2004 (M. P.: Alfredo Beltrán Sierra; mayo 6 de 2004).

45. Corte Constitucional de Colombia. Sentencia T-594/2004 (M. P.: Manuel José Cepeda Espinosa; junio 15 de 2004).

46. Corte Constitucional de Colombia. Sentencia C-1054/2004 (M. P.: Marco Gerardo Monroy Cabra; octubre 26 de 2004).

47. Corte Constitucional de Colombia. Sentencia T-046/2005 (M. P.: Clara Inés Vargas Hernández; enero 27 de 2005).

48. Corte Constitucional de Colombia. Sentencia T-170/2005 (M. P.: Jaime Córdoba Triviño; febrero 25 de 2005).

49. Corte Constitucional de Colombia. Sentencia C-532/2005 (M. P.: Manuel José Cepeda Espinosa; mayo 24 de 2005).

50. Corte Constitucional de Colombia. Sentencia C-003/2005 (M. P.: Jaime Córdoba Triviño; enero 14 de 2005).

51. Corte Constitucional de Colombia. Sentencia C-188/2006 (M. P.: Rodrigo Escobar Gil; marzo 15 de 2006).
52. Corte Constitucional de Colombia. Sentencia C-1000/2007 (M. P.: Humberto Antonio Sierra Porto; noviembre 21 de 2007).

53. Corte Constitucional de Colombia. Sentencia C-032/2008 (M. P.: Marco Gerardo Monroy Cabra; enero 23 de 2008).

54. Corte Constitucional de Colombia. Sentencia C-793/2009 (M. P.: Gabriel Eduardo Mendoza Martel; noviembre 4 de 2009).

55. Corte Constitucional de Colombia. Sentencia T-088/2010 (M. P.: Jorge Ignacio Pretelt Chaljub; febrero 15 de 2010).

56. Corte Constitucional de Colombia. Sentencia T-710/2010 (M. P.: Jorge Iván Palacio Palacio; septiembre 8 de 2010).

57. Corte Constitucional de Colombia. Sentencia C-830/2010 (M. P.: Luis Ernesto Vargas Silva; octubre 20 de 2010).

58. Corte Constitucional de Colombia. Sentencia T-031A/2011 (M. P.: Nilson Pinilla PiniIla; febrero 2 de 2011).

59. Corte Constitucional de Colombia. Sentencia T-810/2011 (M. P.: Mauricio González Cuervo; mayo 20 de 2011).

60. Corte Constitucional de Colombia. Sentencia C-630/2011 (M. P.: María Victoria Calle Correa; agosto 24 de 2011).

61. Corte Constitucional de Colombia. Sentencia T-777/2011 (M. P.: Jorge Ignacio Pretelt Chaljub; octubre 20 de 2011). 
62. Corte Constitucional de Colombia. Sentencia T-207/2012 (M. P.: Juan Carlos Henao Pérez; marzo 15 de 2012).

63. Corte Constitucional de Colombia. Sentencia T-341/2012 (M. P.: Jorge Ignacio Pretelt Chaljub; mayo 14 de 2012).

64. Corte Constitucional de Colombia. Sentencia T-932/2012 (M. P.: María Victoria Calle Correa; noviembre 9 de 2012).

65. Corte Constitucional de Colombia. Sentencia T-416/2013 (M. P.: Mauricio González Cuervo; enero 30 de 2013).

66. Corte Constitucional de Colombia. Sentencia T-413/2013 (M. P.: Nilson Pinilla Pinilla; julio 4 de 2013).

67. Corte Constitucional de Colombia. Sentencia C-313/2014 (M. P.: Gabriel Eduardo Mendoza Martelo; mayo 29 de 2014).

68. Corte Constitucional de Colombia. Sentencia C-818/2014 (M. P.: María Victoria Sáchica Mendez; noviembre 5 de 2014).

69. Corte Constitucional de Colombia. Sentencia C-166/15 (M. P.: María Victoria Sáchica Méndez; abril 15 de 2015).

70. Chapus, R. (2000). Droit administratif général (Décima cuarta ed., t. I), Paris: Montchrestien.

71. García de Enterría, E. y Fernández, T. R. (2008). Curso de Derecho Administrativo (t. II). Bogotá: Temis/Palestra.
72. Gaudemet, Y. (2001). Traité de droit administratif (Décima sexta ed.). Paris: Librairie générale de droit et de jurisprudence.

73. Gil Botero, E. (2011). Responsabilidad extracontractual del Estado (Quinta ed.). Bogotá: Temis.

74. Henao, J. C. (1996). Presentación general de la responsabilidad extracontractual del Estado en Colombia. En Memorias de las Jornadas Colombo-Venezolanas de Derecho Público. Bogotá: Universidad Externado de Colombia.

75. Henao, J. C. (2015). Las formas de reparación en la responsabilidad del Estado: hacia su unificación sustancial en todas las acciones contra el Estado. Revista de Derecho Privado, (28), 277-366.

76. Leguina Villa, J. (1983). La responsabilidad civil de la Administración Pública. Madrid: Tecnos.

77. M'Causland, M. (2013). Responsabilidad del Estado por daños causados por actos violentos de terceros. En C. Bernal Pulido y J. Fabra Zamora (Edits.), La filosofía de la responsabilidad civil. Estudios sobre los fundamentos filosófico-jurídicos de la responsabilidad civil extracontractual (págs. 515-588). Bogotá: Universidad Externado de Colombia.

78. Molina, R. (2013). Causalidad e imputación objetiva en materia de responsabilidad por la prestación del servicio médico (Tesis de Maestría). Universidad Externado de Colombia. Bogotá. 
79. Montaña, A. (2014). Caracterización de la jurisdicción contencioso administrativa coIombiana con ocasión de su reconocimiento como causa y producto del fortalecimiento del Derecho Administrativo. En A. Montaña Plata y A. F. Ospina Garzón (Edits.), 100 años de la Jurisdicción de lo Contencioso Administrativo. "Justificación, retos y aporte al Derecho administrativo". Bogotá: Universidad Externado de Colombia.

80. Papayanis, D. (Ed.). (2013). Derecho de daños, principios morales y justicia social. Madrid: Marcial Pons, Ediciones Jurídicas y Sociales.

81. Pareja, C. (1937). Curso de derecho administrativo teórico y práctico. Bogotá: Librería Siglo XX.

82. Patiño, H. (2015). El trípode o el bípode: la estructura de la responsabilidad. En J. C. Henao y A. F. Ospina Garzón (Edits.), La responsabilidad extracontractual del Estado. Bogotá: Universidad Externado de Colombia.

83. Pimiento, J. (2014). Las acciones populares como instrumento de constitucionalización de la acción administrativa. En La constitucionalización del derecho administrativo (págs. 349-374). Bogotá: Universidad Externado de Colombia.

84. Puigpelat, O. M. (2012). La responsabilidad patrimonial de la Administración. Hacia un nuevo sistema. Madrid: Edisofer.

85. Sánchez Morón, M. (2010). Derecho Administrativo. Parte general (Sexta ed.). Madrid: Tecnos.

86. Santamaría Pastor, J. A. (1991). Fundamentos de Derecho Administrativo (t. I). Madrid: Editorial Centro de Estudios Ramón Areces.

87. Truchet, D. (2015). La evolución reciente de la responsabilidad administrativa en el derecho francés. En J. C. Henao y A. F. Ospina Garzón (Edits.), La responsabilidad extracontractual del Estado. Bogotá: Universidad Externado de Colombia.

88. Upegui J. (2009). Doce tesis en torno al concepto de Estado social de derecho. Discurso jurisprudencial. Elementos. Usos. Bogotá: Universidad Externado de Colombia, Instituto de Estudios Constitucionales Carlos Restrepo Piedrahita. 